\title{
Improving the Experiences of Mothers Struggling with Their Children's Misbehavior
}

\author{
Ş.Hülya KURT ${ }^{a^{*}}$ (ORCID ID - 0000-0002-0211-1463)
}

Ayperi Dikici SIĞIRTMAÇ ${ }^{b}$ (ORCID ID - 0000-0002-8167-8467)

Muzaffer Sencer ÖZSEZER ${ }^{c}$ (ORCID ID - 0000-0002-8963-010X)

a Tarsus Üniversitesi, SHMYO, Çocuk Gelişimi Programı, Mersin/Türkiye

${ }^{\mathrm{b}}$ Çukurova Üniversitesi, Eğitim Fakültesi, Adana/Türkiye

${ }^{c}$ Çukurova Üniversitesi Eğitim Fakültesi Adana/Türkiye

\section{Article Info}

DOI: $10.14812 /$ cufej.947175

\section{Article history:}

Received $\quad 02.06 .21$

Revised 10.08.21

Accepted 17.09.21

\section{Keywords:}

Mothers' perceptions of

misbehaviour

Children's misbehaviour,

Action research,

Physical punishment of children,

Early childhood and parenthood

\begin{abstract}
The aim of this study was to examine the perceptions of mothers' and their children regarding the children's misbehaviour and the mothers' response to it. The research was carried out through the action research approach, which is a qualitative research methodology. The research data were collected through interviews, training evaluations, and participant diaries. The data analysis was carried out using content analysis. The study participants consisted of children attending nursery school in the Anamur district of Mersin, Turkey and the mothers of these children. The action research process began with the interview and observation data from the participating children. In light of the information obtained from these data, interviews were conducted with the mothers to determine their needs as well as identify their difficulties with their children's misbehaviour. As a result of the mothers' interviews, training was prepared utilizing expert opinion to improve the mothers' experiences who had been struggling with their children's misbehaviours. As a result of the study, it was seen that mothers used physical violence as discipline/punishment to address their children's misbehaviour. By analysing the data obtained from the participants, the needs of the mothers struggling with the children's misbehaviours were determined. An action plan was prepared in line with this needs analysis. As a result of the training according to the action plan, it was concluded that the mothers recognized their mistakes and learned from their deficiencies. It was also found that mothers noticed that their relationship with their children had changed positively. Additionally, it was concluded that the trainings should be repeated at certain intervals and that the children's fathers should also participate.
\end{abstract}

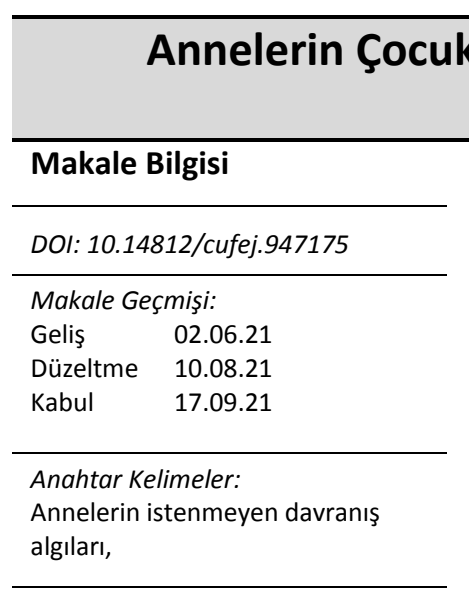

\section{Yaşantılarını Geliştirme} Öz

Bu araştırmanın amacı annelerin ve çocukların istenmeyen davranışlar ile mücadele algılarını incelemektir. Araştırma nitel araştırma yöntemlerinden eylem araştırması yaklaşımıyla gerçekleştirilmiştir. Araştırmanın verileri görüşmeler, eğitim değerlendirmeleri ve katılımcı günlükleri aracılığıyla toplanmıştır. Verilerin analizinde içerik analizi yöntemi kullanılmıştır. Araştırmanın katılımcılarını Mersin ili Anamur ilçesinde bir anasınıfına devam eden çocuklar ve anneleri oluşturmuştur. Çalışmada eylem araştırması süreci çocuklarla görüşme ve gözlem verileriyle başlamıştır. Bu verilerden elde edilen bilgiler ışığında, annelerle gereksinimlerini belirlemek ve istenmeyen davranışlarla mücadelede hatalarını tespit etmek amacıyla görüşmeler yapılmıştır. Bu görüşmeler sonucunda annelerin istenmeyen davranışlarla mücadele yaşantılarını geliştirmek amacıyla uzman görüşü alınarak eğitim içerikleri hazırlanmıştır.

Author: hulyakurt@tarsus.edu.tr 
Çocukların istenmeyen davranışları,

Eylem araştırması, Çocuğa fiziksel şiddet, Erken çcoukluk ve ebeveynlik
Eğitim süreci tamamlandıktan sonra annelerden sömestr tatilinde önleyici uygulamalar ve istenmeyen davranışlar sonrası tepkiler konusunda deneyimlerini kaydetmeleri istenmiştir. Bu belgeler, eğitim sonrası uygulama günlükleri olarak analiz edilmiştir. Veri toplama sürecinin son aşaması olarak annelerle istenmeyen davranışlarla mücadele konusunda tekrar görüşülmüş bu görüşmede sürece ilişkin değerlendirmeleri alınmıştır. Çalışma sonucunda annelerin istenmeyen davranışla mücadelede fiziksel şiddeti kullandığı görülmüştür. Bu doğrultuda oluşturulan eylem planı kapsamında verilen eğitimler sonucunda annelerin yanlışlarını gördüğü ve eksiklerini öğrendiği sonucuna ulaşılmıştır. Annelerin süreç sonunda çocuklarla ilişkilerinin olumlu yönde değiştiğini fark etmeleri çalışmanın bir diğer bulgusudur. Ayrıca eğitimlerin belirli aralıklarla tekrarlanması ve babalarının da katılması gerektiği sonucuna varılmıştır

\section{Introduction}

Every parent feels discomfort when their child misbehaves. Instead of questioning whether the child's misbehaviour is intentional or why such behaviours are triggered, the parents initially opt to classic methods of discipline such as physical punishment to counter these behaviours. However, it is shown in past research that the strategies used by parents to prevent children's misbehaviour, family structure and environment, influence the creation and assistance of these misbehaviours (Gardner, Sonuga-Barke, \& Sayal, 1999; Khan, Quadri, \& Aziz, 2014). It is pointed out in other research that the implementation of physical punishment to correct children's misbehaviour is decreasing worldwide (Clément \& Chamberland, 2014; D'Souza, Russell, Wood, Signal, \& Elder, 2016; Österman, Björkqvist, \& Wahlbeck, 2014). However, this destructive act by parents used to prevent misbehaviour among children, is considered as a form of discipline in many societies. More than one billion children, which is half of the children in the world, regularly face violence (Hillis, Mercy, \& Saul, 2017). According to the latest meta-analysis research regarding physical violence on a global perspective, $55 \%$ of children worldwide are exposed to light physical punishment, and $14 \%$ are exposed to heavy physical punishment (Hillis, Mercy, Amobi, \& Kress, 2016; Stoltenborgh, Bakermans-Kranenburg, Van ljzendoorn, \& Alink, 2013).

Discipline is not related to controlling destructive or unacceptable behaviours displayed by children or adults. Instead, it is related to a safe and valuing environment where people's rights and needs are respected, verified, and protected (Humphreys, 2003). Adults apply corporal punishment under the name of discipline to change the child's current behaviour. Although, it is in fact only effective in triggering anti-social behaviours and disrupting the parent-child relationship. Many studies are focused on the harmful effects of parents' corporal punishment practices on both the parents and their children. The most common effects of corporal punishment are physical and mental problems as well as increased aggression among children and adults along with reduced quality of the parent-child relationship (Breen, Daniels, \& Tomlinson, 2015; Gershoff, 2013; Gershoff \& Grogan-Kaylor, 2016; MacKenzie, Nicklas, Waldfogel, \& Brooks-Gunn, 2013; Park, 2010; Maguire Jack, Gromoske, \& Berger, 2012; Simons \& Wurtele, 2010; Straus \& Paschall, 2009). Additionally, when punished, children often temporarily stop engaging in their misbehaviour. Although, in the absence of parents, children tend to exhibit misbehaviour in the same or more severe manner. In other words, children are often punished and exposed to adverse effects of these punishments but cannot seem to not learn the appropriate behaviour (Oas, 2010).

In many cases, Mothers often become the primary parent who have to deal with their children's misbehaviour, which is mainly due to their more intense interaction and time spent with their kids each day. As a reflection of this, it is shown in studies that mothers in many parts of the world from different cultures and various ways of life are the parents who most often use discipline/punishment to address children's misbehaviour (Chan, 2012; Gryczkowski, Jordan, \& Mercer, 2010; Simons \& Wurtele, 2010; Wauchope \& Straus, 2017). Thus, various programs are implemented for families around the world to reduce inappropriate methods used to address children's misbehaviour. These programs can guide parents in developing effective parenting practices, supporting their children's development, and managing their behaviour. It also provides support, experience, and opportunities for them to develop their knowledge and confidence for appropriately facing the current challenges for raising children 
(Altafim \& Linhares, 2016; Weymouth \& Howe, 2011; WHO, 2009). Research regarding these programs also focuses on the positive effects of intervention programs to prevent punishment and physical violence in parent-child interactions (Coore Desai, Reece, \& Shakespeare Pellington, 2017; Knox, Burkhart, \& Cromly, 2013; Taylor, Manganello, Lee, \& Rice, 2010). Unlike other studies, in this current study, the situation was determined specifically according to the study participants. Additionally, it was focused on the topics that mothers should be supported in regarding their struggles with their children's misbehaviour. During these processes, the research was conducted by receiving continuous feedback from the mothers. Also, in this current study, the use of corporal punishment by the mothers towards the child was initially noticed by the teacher through the interactions of the children with their classmates and other teachers, and it was then determined to initiate the action research process. In this study, the mothers' perceptions of misbehaviours were investigated before and after the action plan was carried out. In line with this purpose, answers were sought to the following research questions:

1- What are children's perceptions of physical punishment against their misbehaviour?

2- What are the mothers' perceptions of physical punishment that they use to address their children's misbehaviour?

3- What are the mothers' perceptions towards their children's misbehaviour following the first cycle of the action plan?

\section{Method}

\section{Research Model}

In this study, an action research design, which is a qualitative research methodology, was utilised. In this context, firstly, the problem that mothers used physical violence against their children's misbehaviour was determined. After identifying this problem, the steps of the action research process were applied. The reason for choosing the action research methodology was that action research aims to solve specific problems within a program, organization, and/or community. This method involves people in the process of change to solve their problems clearly and purposefully (Johnson, 2014; Patton, 2014). Action research is a systematic process for solving problems and making progress in an action. It is concerned with solving the problem feasibly and effectively (Tomal, 2010). In action research, teachers can plan and implement research, as they have more information regarding events and phenomena that occur within their classroom than someone looking in from the outside (Kuzu, 2009). In this research, the teacher identified the problem situation as "the presence of physical violence in the family." Later, the teacher created an action plan to solve the problem that emerged in the role of researcher and became its implementer. Thus, the action research cycle was put into practice.

\section{Data Collection Tools}

The data collection tools used in this research were interviews, post-training evaluations, and participants' diaries. All data collection tools used in this study were prepared and applied in Turkish. In line with the purpose of the study, these tools were utilised to determine the perceptions of mothers and children against the children's misbehaviour. Semi-structured interview questions were prepared by the researcher. These questions were prepared for implementation after gaining expert opinion as well as making the necessary changes according to their suggestions. The interviews were recorded with a voice recorder. Interview questions consisted of nine questions for mothers and six questions for children. These questions were prepared as open-ended questions to reveal the perceptions of mothers and children regarding the misbehaviours. The questions were used at the outset of the study to determine the current situation and problem. The same questions were again used at the end of the study to understand any change in the participants perceptions. Each interview lasted approximately 15 to 20 minutes. A training seminar evaluation document was presented to the mothers after each seminar. This data collection tool consisted of four open-ended questions in which achievements were stated as well as the experiences were associated with the topics in the seminar. While in the participant diaries, which was another data collection tool used, the mothers were asked to write both 
the practices to prevent their children's misbehaviour as well as their reactions. For participant diaries, the holiday period, in which the children were together with their mothers for an extended time, were used as a time to complete the diary.

\section{Participants}

The study participants consisted of children attending preschool at the Fatih Primary School in the Anamur district of Mersin, Turkey and the children's mothers. For this purpose, 20 participants were interviewed to start, but eventually 12 volunteered to participate in the research. Some of the mothers left the research at different stages of the research due to issues related to their health or work or finding the research unnecessary. Ultimately, the research was carried out and completed with eight volunteer mothers. Purposive sampling method, which is based on strategically and purposefully determining information-loaded situations, was utilised in selecting the research sample. Convenience sampling, a form of purposive sampling preferred to save time, money, and effort, was used. The participants consisted of eight mothers living in the centre and central villages of Anamur district in Mersin province, Turkey. One of the mothers was a nurse, three were seasonal agricultural laborers, and four were housewives. The mothers' ages ranged between 28 and 42 . Seven of the mothers lived in the district centre, and one of them within a central village. Four of the mothers had three children each, while four mothers had two children each. When the mothers' educational levels were considered, it was found that two were graduates of high school, two graduates of secondary school, and four graduates of primary school. The participating children were students of a preschool educational institution, and their ages ranged between 60 and 72 months. Among the children, five were boys and three were girls. An informed consent form was obtained from the participants who voluntarily participated in the study.

\section{Data Collection Process}

The data collection process of this study, which was conducted to examine mothers' perceptions regarding their children's misbehaviour before and after the action plan, continued until the first cycle of the action research was completed. In this direction, the data collection process; consisted of determining the current situation and problem, documenting the experiences prior to the action plan, the action plan process, and the evaluation of the action plan. The data collection process started with determining the current situation and the related problems in September-October 2018, when the schools were opened, and then ended with a participant evaluation interview in the month of April.

\section{Action research process}

The research began with the current situation and the determination of the problem, then the first cycle ended with the participant evaluation interviews. The action research process began with the determination of a problem and action topic. The process included making plans to collect data as well as collecting, analysing, and organizing the data, reporting on the data, presenting conclusions, and recommendations along with making an action plan, practicing, and evaluating the action plan. First, the mothers' perceptions regarding their children's misbehaviour were gathered. Then, they were asked to compare what was presented in the presented training seminars with their own personal experiences and to evaluate them. To better understand the reflection of the training on their lives, 15-day diaries were completed, which included the semester holiday period in which they had much of the interaction with their children. Finally, the mothers' perceptions regarding their children's misbehaviour were again gathered, and then they were asked to evaluate the process as a whole.

The process of determining the current situation and the recognised problem started with the researcher's realisation of the problem of mothers using physical violence to correct their children's misbehaviour. Following this initial determination, observations and communications made throughout the daily training were noted. According to these notes, the children stated that their mothers punished them, and they used physical violence as punishment. The widespread use of physical violence by mothers is a problem needing to be solved. The researcher asked the children what happened if they did not obey the rules while forming the classroom rules at the beginning of the semester. Some of the 
KURT, Dikici SIĞIRTMAÇ, ÖZSEZER - Çukurova Üniversitesi Eğitim Fakültesi Dergisi, 50(2), 2021, 1184-1209

children's responses to that question were as follows: "We are punished," "If I do not tidy up my room, my mother gives me the room punishment," "When I play with the ball at home, my mother beats me", and "My mother has a stick."

Another data collection tool was used to determine the current situation and problem. This tool was semi-structured interview questions created to learn the participants' perceptions of the misbehaviour. Questions were asked to the mothers and children separately and these processes were recorded with an audio recorder. As a result of the interview analysis, the titles and contents of the training seminar process, which is the next step, were determined. In the context of the current situation and the identified problems, educational presentations were prepared by the current researchers regarding subjects necessary for the mothers. Afterwards, the prepared seminar process was applied together with the mothers on the days and times determined. The trainings were prepared as five seminar sessions in December. It was presented by the researcher in a seminar format every week. The seminar processes conducted with mutual interaction were video recorded. Following each seminar, participant evaluations were taken. In these evaluations, the participants were asked to relate their opinions about the seminar and their experiences with what information was provided in the seminar. Additionally, the participants filled out application diaries showing whether the trainings were reflected in their lives or not. It was thought that with the coming of the midterm break after the education period, the mothers would interact more intensely with the children. For this reason, they were asked to write about what they believed were the reasons for the formation of their children's misbehaviour as well as their reactions during the holiday break time. The notes of the mothers were recorded as application logs.

Finally, interview questions were asked again to evaluate the process by the participants. Additionally, at the end of the interview, mothers were asked to evaluate the action plan process. In this way, the first cycle of the action plan was completed. The data collection process is presented in Table 1.

Table 1

Data Collection Process

\begin{tabular}{lll}
\hline \multicolumn{1}{c}{ Activity } & Date/Period & \multicolumn{1}{c}{ Content } \\
\hline $\begin{array}{l}\text { Determination of the current } \\
\text { situation and problem }\end{array}$ & $\begin{array}{l}\text { September- } \\
\text { October }\end{array}$ & Notes of researcher and children's interaction \\
& & Informing and inviting the mothers \\
& Doing interviews with the mothers and children
\end{tabular}

\section{Action Process (December)}

Session 130 minutes Providing a seminar on "Punishment, Physical Violence, and their effects on children."

Session $2 \quad 25$ minutes A presentation of the research results on "Physical Violence on children and its effects worldwide."

Participants' evaluations after Session 1, 2

Session 345 minutes The latest policies on 'Children's Rights' and preventing physical violence on children as punishment in the world

\begin{tabular}{cll}
\hline Participants' evaluations after Session 3 & \\
\hline Session 4 & 45 minutes & Effective Child-Parent communication skills \\
Session 5 & 45 minutes & $\begin{array}{l}\text { A presentation on preventing children's } \\
\text { misbehaviour and techniques of guiding children to } \\
\text { correct behaviour }\end{array}$
\end{tabular}

An expert opinion video on punishment-reward for 
children and effective communication skills (Prof. Dr. Üstün Dökmen)

\begin{tabular}{lll}
\hline Participants' evaluations after Session 4/5 & \\
\hline Perceptions after the training & $\begin{array}{l}\text { Semester } \\
\text { Holiday }\end{array}$ & $\begin{array}{l}\text { Diary about the reasons for misbehaviour and } \\
\text { experiences regarding the reactions } \\
\text { Evaluation of the process }\end{array}$ \\
$\begin{array}{ll}\text { Last week of } \\
\text { March }\end{array}$ & $\begin{array}{l}\text { Doing interviews with the mothers and getting the } \\
\text { evaluations }\end{array}$ \\
\hline
\end{tabular}

\section{Data Analysis}

The researcher began to itemize the recordings after finalizing the interviews. Following the transcriptions, the children were coded with the initial letter of their names, and mothers were added next to their children's names ( $\mathrm{H}$. mother). The data in the written recordings were analysed through content analysis by gaining expert opinions. In the first stage, the collected data were classified and arranged. Then, all were read and examined. Next, the data were categorized and coded as a representative word writing process (Creswell, 2014). Appropriate themes to express these categories were defined, and the codes, categories, and themes were presented to an expert coder for their opinion on the principle of credibility. Importantly, in these scenarios, multiple coding is done to reduce the risk of subjectivity during the analysis process in providing validity and reliability within qualitative research (Silverman, 2015). For this reason, according to a process known as researcher triangulation, a second coder, participated in the data coding process of this study. Thus, the aim was to provide a cross query interpretation of the data. Similar to Barbour (2001), the compatibility level of the two coders was determined as $88 \%$, and a joint decision was made by the coders regarding differing codes. As a result, 19 categories and five themes which were obtained from the codes following the arrangement of the results, are presented in Table 2.

Table 2.

Themes regarding the Cycle of Action Plan

\begin{tabular}{|c|c|}
\hline Themes & Categories \\
\hline \multirow{5}{*}{$\begin{array}{l}\text { Perceptions of children regarding } \\
\text { punishment }\end{array}$} & Definition of punishment \\
\hline & Punishments that were imposed \\
\hline & Reason of punishment \\
\hline & Emotions after punishment \\
\hline & Alternatives \\
\hline \multirow{6}{*}{$\begin{array}{l}\text { Perceptions of mothers' regarding } \\
\text { punishment }\end{array}$} & Definition of punishment \\
\hline & Punishments that were imposed \\
\hline & Reason of punishment \\
\hline & Emotions after punishment \\
\hline & Acceptable violence \\
\hline & Alternatives \\
\hline \multirow[t]{3}{*}{ Evaluation of the training } & Initial emotions following the training \\
\hline & Comparing the experience with the training \\
\hline & Expectations for the future \\
\hline \multirow{2}{*}{$\begin{array}{l}\text { Experiences regarding practices following } \\
\text { the training }\end{array}$} & Finding the reason for misbehaviour \\
\hline & Practices against misbehaviour \\
\hline Perceptions following the Action Plan & $\begin{array}{l}\text { Perception of punishment following the training } \\
\text { Evaluation }\end{array}$ \\
\hline
\end{tabular}




\section{Findings}

In this section, the first of the findings obtained from the data analysis are presented including the perceptions of mothers and their children regarding the use of physical violence as discipline/punishment against misbehaviour. In the next section, mothers' perceptions of their children's misbehaviour are included following the first cycle of the action plan. Finally, in the findings section, the evaluations of the mothers regarding the action plan process are included.

\section{1- Findings Concerning Children's Perceptions of the Use of Physical Violence for Punishing their} Misbehaviour

Most of the children in the study described the punishment as being equivalent to their misbehaviour in the interviews: "When I pull my elder sister's hair." (A. S.) "They impose punishment to me when I do something bad."(R) Many children expressed that they were exposed to the physical violence most often by their mothers. Some of the children declared that they were punished for tidying up the toys and gave a pause. One of the children who said that he had been exposed to physical violence reflected on his experiences as follows: "She beats me. For example, she beats me on my arm. Then, she beats me on my other leg. She pinches me. There is nothing else." (R)

Moreover, the children said that they were punished when they did not comply with their mothers' requests, and they had problems with their siblings as follows: "When I make my sibling cry." (V) "For example, when I go out, take her belongings or take a glass outside without my mother's permission." (H.A.) In this particular research, all the children but A.S. stated that they were exposed to physical violence by their mothers.

In this research, the children were asked about their feelings when their mother used physical violence as punishment. All of the children expressed that they felt sad. One child said that he also felt angry, and another child said that he also felt bad: "I cried. I had tears on my face. (U) "Sad." (E) The children were asked what reactions of their mothers would be better instead of beating and it was seen that many of them said that they did not have any idea, one of them said that he might help his mother, one child said that his mother had to make him sit and another child said that his mother could make him tidy up his room: "I don't know. I don't want her to beat me. I don't know." (M.A.) "In my opinion, if I help her, she won't punish me again. I will please her. In other words, I will make her happy." (H.A.)

\section{2- Findings Concerning Mothers' Perceptions on the Use of Physical Violence When Struggling with their Children's Misbehaviour}

When the mothers' definitions of punishment were considered within this study, it was determined that the expressions of enforcement, prevention, and the equivalent of fault or misbehaviour were repeated. There were also some responses admitting that the punishment was terrible but necessary, it was preferred when the children disobeyed, and it meant stopping and restraining the children. It was determined in this study that the most commonly used punishments were physical violence, deprivation, verbal violence, pause, threatening, and behaving as if offended, respectively, in terms of intensity. All but one of the mothers declared that they used physical violence. It was observed that deprivation was the other most commonly used punishment method by nearly half of the mothers: "I only beat, I do not impose any other punishment. For example, I get furious. They make me feel furious. Yes, I yell at them. They do not go to their rooms when I tell them to." (M.A. mother). Mothers used the punishments randomly without a particular systematic approach. Some mothers said they preferred the punishments according to their mood or decided on the punishment according to the type and level of the misbehaviour. One mother expressed that her mood was indicative of the punishment as follows: "Honestly speaking, I sometimes yell at them. It is related with my psychology when I am calm." (A.S. mother). Another mother expressed that she decided on the punishment according to the effect of the misbehaviour on her: "We may evaluate according to his misbehaviour. I do not punish him for small things. He should go beyond himself in terms of misbehaving to be seriously punished." $R$. mother). 
The participant mothers specified that they preferred to punish the children when they did not fulfil their responsibilities (not tidying up what they messed up) or they did not do what their mothers wanted them to do: "When he does not do what I tell him to do and when he does just the opposite what I said." (E. mother). All of the mothers but one in the study expressed that they commit physical violence as a way for changing their children's behaviour: "This happened. I beat him. I cannot tell lies. I beat on his backside and hands. I admit that I also beat him on his face in the past." (A.S. mother). In the study, most mothers used the expressions of "sometimes, only to his hands, to his backside, slightly and to some parts of his body," which showed that the physical violence they committed was reasonable.

The participant mothers had consensus on the feeling of mothers and children after they committed physical violence on the children. All of the mothers who committed physical violence expressed that the children felt sad, and they felt regret as follows: "He feels sad. For example, he asks, "Mom, don't you love me?. Then I feel regret. I question myself. Why did I do this? Why did I beat on him?. I wish I had not to beat like that" (M.A. mother). The participant mothers specified that they did not know any positive behaviours for changing their method of punishment.

\section{3- Findings Concerning the Perceptions of Mothers Regarding Struggling with Children's Misbehaviour Following the Action Plan}

The mothers were instructed to evaluate the seminars through open-ended questions. In the evaluations of the mothers, it was striking that the mothers' own experiences made them realize their regrets and mistakes in their perceptions of violence. One of the mothers mentioned the effects of physical violence on the child as follows: "I was beating slightly and I thought it was not considered violence, but it was violent in fact. We have learned that our children also have rights. I felt sorry as I damaged my child." (U. mother). The mothers expressed their deficiencies in being consistent and determined about the methods which they preferred against their children's misbehaviour. One of the mothers stated as follows that they were focusing on how they would react to the misbehaviour rather than questioning the reasons for the misbehaviour: "When the child beats his sister, he should be asked to say why and how he did it instead of punishing him directly. I will use I-language." (H.A. mother). In their evaluations, the mothers mentioned the behaviour-changing methods alternative to violence, which were emphasized in the seminar, and they remarked that they would try to change their practices: "I have learned the difference between punishment and discipline. I have learned how to build communication with my child and how to listen to him. I have learned how effective I-language is in communication. I am going to try to communicate with my child through I-language." (A.S. mother). When the mothers evaluated what they were told in the seminar in the context of the interactions with their own children, they emphasized the issues of talking, listening, and rewarding the child instead of the statement of a command. They stated the differences between their experiences and what they were told in the seminar: "I was always rewarding my child by buying something for him. However, I have noticed that it was enough to do this with love." (U. mother).

The mothers reviewed their plans about what they could do against their children's misbehaviour in their own experiences by emphasizing consistency and determination: "I'm going to display behaviours that have continuity, consistency, and determination. I have noticed that I didn't spend enough time with my child, and I wasn't communicating with my child correctly." (A.S. mother). The mothers were asked to try to find the possible reasons of their children's misbehaviour during their communication in the semester holiday in which they would spend more time with their children and write them in their diaries. When these diaries were considered, it was found that being jealous of the sibling, being unwilling to tidy up the toys, wishing to attract attention, and demanding unlimited opportunities were the primary reasons leading to the misbehaviour: "My child displays this behaviour when we do not do the things he wants. This is because we do all things he wants."(B. mother). When the expressions of the mothers were considered, it was seen that I-language and playing with the children were especially effective in changing the behaviours. Some mothers stated that they had difficulty in anger management, and some of them mentioned that they could not have a chance for interaction in changing the behaviours. On the other hand, most of them expressed positive results when they spent 
time and used effective communication skills: "He throws his clothes everywhere. When I say that I feel sorry and I will spend some time which I can spend with him on putting his clothes away, I can see that he picks up his clothes and puts them away into his wardrobe." (H.A. mother).

The mothers were interviewed once again to reveal their perceptions regarding their practices against their children's misbehaviour, and they were instructed to evaluate the process. The mothers defined punishment as the practice used against their children's misbehaviour. They stated that they used these practices in specific situations. When the mothers were asked about their attitudes towards their children's misbehaviour, they expressed that they used to beat, but they made a point of talking with them and making them think about the misbehaviour: "I was saying that I used to beat. I started to be patient and not to beat from then on. I tell him 'Let us think about this. Why did you do this? I am feeling sorry now." (V. mother). Additionally, the mothers stated that they applied some of the behaviour change methods described in the seminar: "I used to send it to the mop before. Now I am warning and speaking first. I am explaining what can happen as a result of his/her behaviour."(U. mother). Mothers explained that among the behaviour change methods described in the seminar, they most often used the method of talking and referring to thinking: "I am sending you in. I am looking. So, it does. He hugs and apologizes. I am talking a lot. I say I am sad. Look, I am saying it could be this way." (M. mother).

\section{4- The mothers' evaluations of the action plan process}

When the mothers were talking about the positive effects of the trainings from the seminars on their perceptions and experiences, they mentioned that committing physical violence to the child would negatively affect both themselves and their children: "I have understood how negatively my child will be affected. He will behave the same way to his children in the future. He will be aggressive. I have felt that the importance of the issue and I have also noticed that there is no more or less violence. I remembered the times I beat my child and I felt really sorry" (A.S. mother). Additionally, they also expressed that they were trying to talk to the children about the misbehaviour, used positive communication, and tried to solve the problem instead of shouting and committing physical violence that has destructive effects, as they were told in the seminars. One of the mothers said that she started to spend more time and play with her children more often than she did in the past, did time-consuming activities that would provide them interaction at home, and she was not worried that the house would become messy: "I used to go mad and get angry when my child annoyed me but now I reach down, kiss, and tickle him. I don't use the slippers anymore, now I wrestle with him. I talk to him. Now I can see that the things I used to shout at were silly things. I don't care the house becoming messy anymore. I made a cake yesterday and I told him to pour the baking powder. They like it. I let the house become messy. I can tidy it up in an hour when they go to sleep." (H. mother).

Most of the mothers stated that they saw this kind of study for the first time and found it very beneficial. They also emphasized that this kind of training should be done more frequently and having them frequently made them remember what they learned. Some of the mothers claimed that these trainings should also be given to fathers: "Such training should be given more frequently. I recommend this. We sometimes forget. We should be reminded, and it must always be kept on the agenda. Fathers can join this training. My husband sometimes beats our child." (A.S. mother). One of the mothers mentioned that they lived together with the grandparents and uncles in the same building. She added that they affected the children's development negatively, especially in obeying the rules by making wrong interventions: "I tell myself to be determined, but my child gets the support of them. He goes upstairs near them immediately. I try to tell them, but they do not understand. When the child sees his grandmother, his parents lose importance." (B. mother).

\section{Discussion \& Conclusion}

It was concluded in this current study that mothers used physical violence when struggling with their children's misbehaviour. In a study regarding violence in family's carried out with 1886 children aged 7 to 18 -years-old in 2010, determined that $45 \%$ of children are punished with physical violence (Müderrisoğlu, Dedeoğlu, Akço, \& Akbulut, 2014). Belon (2014) investigated the description of corporal 
punishment by individuals, intergenerational communication, relationships with families, and its effect on psychological-emotional well-being and finds that $60 \%$ of the participants are against corporal punishment, and $70 \%$ of them use spanking. It is determined that many of these punishments consist of actions such as beating on the child's arm and pinching. It is also revealed in these studies that $1 / 3$ of children aged 3 to 5 -years-old were victims of violence, and that mothers most often commit physical violence to their children. The reason of this is suggested as the mothers spend more time with the children, so the children are more likely to be victims of violence (Chan, 2012; Wauchope \& Straus, 2017).

In this study, the mothers used reasonable expressions to gloss over physical violence and show it as practical such as beating slightly on the children's hands or backsides while they defined physical violence as a discipline method they used for their children. While in other studies, it was also observed that the parents use simple expressions such as slight and ordinary to gloss over the corporal punishment methods they use (Ateah \& Durrant, 2005; Fréchette \& Romano, 2017). In our study, the mothers stated that they rarely or at times used physical violence. At the same time, the children expressed that their mothers used physical violence such as beating, pinching, pulling hair, and/or pressuring against their misbehaviour. This can be because either the mothers' responses did not reflect the reality, or the children wanted to verbalize the physical violence continuously due to its effect on them. It was concluded in other studies that the children aged between 2 and 4 are exposed to physical violence by their parents most frequently by spanking, pinching, pulling hair, and using an object like belt/cable/stick, respectively (Bell \& Romano, 2012; Fréchette, \& Romano, 2017; Straus, 2010; Zolotor \& Puzia, 2010). In this particular study, when the determiners of the mothers' physical violence preferences were considered, it was revealed that some of the mothers were affected by their mood at the time of the misbehaviour, and some of them chose the kind of physical violence according to the misbehaviour of the children. Another study similarly concluded that the cognitive and affective characteristics of mothers are effective on their decisions regarding the use of physical violence on their children (Ateah \& Durrant, 2005). Additionally, studies have revealed a positive relationship between the level of belief in the usability of corporal punishment and the potential for physical child abuse. Another result of the studies was that parents who declared a firm belief in corporal punishment have high parenting stress (Bardi \& Borgognini-Tarli, 2001; Cappa \& Khan, 2011; Crouch \& Behl, 2001; MacKenzie et al., 2013; Tayfirmet al., 2016). In this study, it was observed that the mothers preferred punishment if the children did not fulfil their responsibilities (not tidying up the things) and/or did not perform what their mothers wanted them to do. The other reasons which prompted the mothers to punish the children were found as damaging objects, committing violence to siblings, and being stubborn. In the related literature, the reasons of mothers' physical violence to their children were sorted as the mother's not finding the child's behaviour correct, motherhood attitude towards corporal punishment, the mother's perception of the seriousness of the child's misbehaviour and intention as well as the mother's anger as a reaction to the child's misbehaviour (Ateah \& Durrant, 2005; Taabur, 2015; Taylor et al., 2016; Winstok, 2014).

In the current study, it was determined that the children felt sadness due to their mothers' punishment and physical violence on them. Very few children thought that it would be better for their mother to give responsibilities instead of committing physical violence, and many of them did not know alternative discipline methods. However, the children did not want to be exposed to physical violence by their mothers when they misbehaved. It was also revealed that the participant mothers felt sorry and regretted committing physical violence, but they did not know any alternative behaviour-changing methods. Similarly, other studies show that the mothers use corporal punishment although they do not approve and consider corporal punishment as appropriate and they do not know any non-punitive discipline methods (Cappa \& Khan, 2011; Gagné, Tourigny, Joly, \& Pouliot-Lapointe, 2007; Romano, Bell, \& Norian, 2013). In the evaluations following the training, it was observed that the mothers emphasized their own regrets and mistakes in the experiences of communication with their children. It was also presented that the mothers did not question the reasons for the misbehaviours as well as did not have any information about the results of committing physical violence to children for changing their behaviour. In accordance with the studies conducted regarding this issue, the importance of increasing 
the efficacy of the communication between parents and their children in child development is overemphasized and it is underlined that training, such as parenting, are necessary for a healthy family life (Bağatarhan \& Nazlı, 2013; Chavis et al., 2013; Ersoy, Kurtulmuş, \& Tekin, 2014).

In the diaries collected in our study, feeling jealous of siblings, not wanting to tidy up things, wanting to attract attention, demanding things continuously were listed as the children's misbehaviours. Furthermore, the mothers expressed that they could not take care of their children and spend time together due to domestic and work responsibilities. When the related literature was reviewed, it was seen that there is a relationship between the parents' attitudes and children's behaviours, and that parents' not being able to take care of their children may be a result of the children's misbehaviour (Aydoğdu \& Dilekmen, 2016; Waller et al., 2012; Yurduşen, Erol, \& Gençöz, 2013). While in this current study, the mothers described their experiences which showed that using practical communication skills (I-language) to address their children's misbehaviour as well as preventing the environment from devolving out of control resulted in preventing misbehaviour (playing with the children, presenting alternative activities) and was influential in better communication with the children. Gordon (2001) expresses that the main message which you-language aims to provide is devoted to the children's personality and self-respect rather than the misbehaviour itself. In contrast, I-language highlights the effects of the children's misbehaviour. Additionally, it shows the parents as real people who are honest and able to build meaningful relationships with their children, and it also aids in the development of deeper relationships. In our study, it was recognised that the mothers' evaluations following the training underlined the importance of communicative language used with the children as well as listening to them by questioning the implementation of discipline. Moreover, it was also found that they determined the mistakes that most participants made and their lack of knowledge, and they expressed that the mothers needed to be consistent and determined. When the related literature was reviewed, it is concluded in the studies that inconsistent discipline of the mother causes an increase in the externalization behaviour of the child, and extroverted behaviour of children was more likely related to the discipline method used than inconsistent discipline in general (Gryczkowski et al., 2010; Keyes et al., 2015).

When the mothers' perceptions regarding misbehaviour were considered following their evaluations regarding training and semester holiday diaries, it was determined that they used practices such as talking with their children and having their children think about their misbehaviour more intensively than they wanted to use physical violence as a discipline method. Besides, the mothers stated that they spent more time with their children and prioritized mother-child interactions to prevent their children from misbehaving. When the results of the intervention programs designed for the parents who committed corporal punishment were taken into consideration, it was similarly concluded that the parent's attitudes could be guided to use less corporal punishment, and the parents could be instructed that they should not use corporal punishment (Chavis et al., 2013; Holden, Brown, Baldwin, \& Caderao, 2014; Scholer, Hamilton, Johnson, \& Scott, 2010). It was observed in the mothers' evaluations that the seminars provided during the action research process were found by them to be constructive, and also stated that the seminars should be repeated more frequently. When past research conducted was considered, it was found that there were studies which were focused on investigating the positive effects of parental training and support programs on both the children's development and parents' personal development (Bağatarhan \& Nazlı, 2013; Bekman \& Atmaca Koçak, 2011; Östberg, Hagekull, Lindberg, \& Dannaeus, 2005; Ritter, 2003). The mothers mentioned that the studies which included the father in the process would be more effective in solving the problem in addition to considering the process helpful for themselves to develop. Another finding of this study was that the mothers expressed that the interventions of the family elders into the interactions of their children caused problems in addressing the children's misbehaviour. It is also determined in other research that living together with grandparents affected intra-family relationships and that parents have to impose strict discipline to prevent children's negative behaviour which were displayed as a result of the grandparents' overly tolerant attitudes (Özyürek \& Tezel Şahin, 2005; Yavuzer, 2003).

According to the results in this study, the mothers need support to improve their struggle regarding their children's misbehaviour. In this context, updating the content of undergraduate and associate 
KURT, Dikici SIĞIRTMAÇ, ÖZSEZER - Çukurova Üniversitesi Eğitim Fakültesi Dergisi, 50(2), 2021, 1184-1209

degree programs on parent education can help new and practical approaches reach the family. In the study findings, it was also seen that the teacher identified the problem situation through their interactions with students in the classroom. In this context, the needs of teachers who are close to parents in terms of family education and participation can be determined. In line with these needs, field experts can prepare subject headings and in-service training can be organized. Through this training, the skills of teachers who frequently interact with parents can be improved in regard to family education and participation. After this training, teachers in each school can organize seminars at regular intervals by conducting a needs analysis according to their experiences with students misbehaviours and communicating with students. Local governments and policymakers can take initiatives to encourage the implementation of these seminars throughout the society. The efficiency of the seminars can be increased by inviting field experts from universities to provide their expertise. Studies can be conducted regarding the conditions required for fathers' to participate where low participation levels are found within the education processes. Furthermore, experimental research can be planned on the effects of this training on children's development in a variety of areas. Studies on parents' perceptions of struggling with children's misbehaviour from different age groups can be planned, and the results compared.

All rules in the "Directive for Scientific Research and Publication Ethics in Higher Education Institutions" have been adhered to. None of the "Actions Contrary to Scientific Research and Publication Ethics" included in the second section of the Directive have been implemented. 


\section{Türkçe Sürümü}

\section{Giriş}

Çocuklarının istenmeyen davranış göstermesi durumundan her ebeveyn rahatsızlık duyar. Çocuğun yaptığı davranışın istenmeyen olup olmadığı ve nedenlerini sorgulamak yerine ilk anda istenmeyen davranışla mücadelede genellikle fiziksel ceza gibi klasik yöntemler uygulanmaya koyulur. Oysa araştırmalar ebeveynlerin istenmeyen davranışı önlemeye yönelik kullandıkları stratejilerin, aile yapısı ve ortamının istenmeyen davranışların oluşumunda ve desteklenmesinde etkili olduğunu belirtmektedir (Gardner, Sonuga-Barke ve Sayal, 1999; Khan, Quadri ve Aziz, 2014). Bazı araştırmalar dünyada çocukların istenmeyen davranışlarına karşı bedensel ceza uygulamasının azaldığına işaret etmektedir (D'Souza, Russell, Wood, Signal ve Elder, 2016; Clément ve Chamberland, 2014; Österman, Björkqvist ve Wahlbeck, 2014). Ancak hala ebeveynlerin çocuklarının doğru davranış göstermesi amacıyla uyguladığı bu yıkıcı tutum birçok toplumda disiplin adı altında yer bulmaktadır. Dünya çocuk nüfusunun yarısı olan 1 milyardan fazla çocuk, şiddete maruz kalmaktadır (Hillis, Mercy ve Saul, 2017). Küresel bir perspektiften fiziksel şiddeti araştıran son meta-analiz çalışmalarına göre, dünya çapındaki çocukların \%55'i hafif bedensel cezaya, \%14'ü ise ağır fiziksel cezaya maruz kalmaktadır (Hillis, Mercy, Amobi ve Kress, 2016; Stoltenborgh, Bakermans-Kranenburg, Van ljzendoorn ve Alink, 2013).

Aslında disiplin çocuklar veya yetişkinler tarafından sergilenen yıkıcı veya diğer kabul edilemez davranışları kontrol etmekle ilgili değildir. Insanların haklarına ve ihtiyaçlarına saygı duyulduğu, onaylandığı, korunduğu güvenli ve değer verilen bir ortamla ilgilidir (Humphreys, 2003). Yetişkinler çocuğun mevcut davranışını değiştirme amacıyla disiplin adı altında bedensel ceza uygulamaktadır. Aslında sadece anti-sosyal davranışları tetikleme ve ebeveyn-çocuk ilişkisini bozmada etkili olmaktadır. Nitekim yapılan araştırmalarda anne-babaların bedensel ceza uygulamalarının hem ebeveyn hem de çocuk üzerindeki olumsuz etkilerine odaklanmıştır. Bu uygulamaların en sık görülen etkileri fiziksel ve ruhsal problemlerin yanı sıra çocukların ve yetişkinlerin saldırganlığının artması ve ebeveyn-çocuk ilişkisinin kalitesinin düşmesidir (Breen, Daniels ve Tomlinson, 2015; Gershoff, 2013; Gershoff ve GroganKaylor, 2016; Maguire Jack, Gromoske ve Berger, 2012; Straus ve Paschall, 2009; MacKenzie ve diğerleri, 2013; Park, 2010; Simons ve Wurtele, 2010). Ayrıca çocuklar cezalandırılarak geçici olarak istenmeyen davranışı bırakırlar. Ebeveynlerin yokluğunda ilk fırsatta aynı belki daha şiddetli olarak bu davranışlarını sergileme eğilimindedirler. Diğer bir deyişle çocuk cezalandırılır ve olumsuz etkilere maruz kalır ancak uygun davranışı öğrenemez (Oas, 2010).

Özellikle daha yoğun etkileşim içinde olma ve günün uzun bir zamanını beraber geçirme nedeniyle anneler çocuğun istenmeyen davranışları ile ilgilenmek durumunda kalan ebeveyn olmaktadır. Bunun bir yansıması olarak annelerin dünyanın bir çok yerinde farklı kültürlerde ve çeşitli şekillerde çocukların istenmeyen davranışlarına en çok şiddet uygulayan ebeveynler olduğunu gösteren araştırmalar yer almaktadır (Chan, 2012; Gryczkowski, Jordan ve Mercer, 2010; Simons ve Wurtele, 2010; Wauchope ve Straus, 2017). Çocuğun istenmeyen davranışı karşısında kullanılan bu uygunsuz yöntemler ile mücadelede tüm dünyada ailelere yönelik çeşitli programlar uygulanmaktadır. Bu programlar, ebeveynlere etkili ebeveynlik uygulamaları geliştirmeleri ve çocuklarının gelişimini destekleme davranışlarını yönetme yönünde rehberlik etmektedir. Ayrıca çocukları yetiştirirken mevcut zorluklarla uygun şekilde yüzleşme konusundaki bilgi ve güvenlerini geliştirmeleri için destek, deneyim ve fırsatlar sağlar (Altafim, ve Linhares, 2016; Weymouth, ve Howe, 2011; WHO, 2009). Bu programlara yönelik yapılan araştırmalar da ebeveyn-çocuk etkileşimlerinde ceza ve fiziksel şiddeti önlemeye yönelik müdahale programlarının olumlu etkilerine odaklanmaktadır (Altafim, Pedro ve Linhares, 2016; Coore Desai, Reece ve Shakespeare Pellington, 2017; Knox, Burkhart, ve Cromly, 2013; Taylor, Manganello, Lee ve Rice, 2010). Diğer araştırmalardan farklı olarak bu araştırmada çalışmanın katılımcılarına özel olarak mevcut durum tespit edilmiştir. Daha sonra istenmeyen davranışla mücadele konusunda annelerin eksikleri üzerine odaklanılmıştır. Bu süreçler sırasında annelerden sürekli geribildirimler alınarak 
araştırma yürütülmüştür. Mevcut araştırmada ailede çocuk üzerinde bedensel ceza sorununun varlığı çocukların sınıf arkadaşları ve öğretmenleri ile etkileşimleri aracılığıyla öğretmen tarafından fark edilmiş ve eylem araştırması sürecinin başlatılmasına karar verilmiştir. Çalışmada eylem planı öncesi ve sonrasında annelerin istenmeyen davranışlarla mücadeleye yönelik algıları araştırılmıştır. Bu genel amaç doğrultusunda çalışma aşağıdaki araştırma sorularına cevap aramaktadır;

1- Çocukların istenmeyen davranışlarına karşı uygulanan fiziksel şiddete yönelik algıları nedir?

2- Annelerin istenmeyen davranışlarla mücadelede kullandıkları fiziksel şiddete yönelik algıları nedir?

3- Eylem planının ilk döngüsü sonrasında annelerin istenmeyen davranışlara yönelik algıları nedir?

\section{Yöntem}

\section{Araştırma Modeli}

Bu araştırmada nitel araştırma yöntemlerinden eylem araştırması deseni kullanılmıştır. Bu kapsamda önce annelerin çocuklarının istenmeyen davranışlarına karşı fiziksel şiddet uyguladıkları sorunu belirlenmiştir. Sorun tespiti aşamasından sonra eylem araştırmasının diğer basamakları uygulanmıştır. Bu çalışmada eylem araştırması yönteminin tercih edilmesinin nedeni eylem araştırmalarının bir program, örgüt ve topluluktaki özel problemleri çözmeyi amaçlamasından kaynaklanmaktadır. Bu yöntem insanları kendi problemlerini çözmeleri için açık ve amaçlı bir şekilde değişim sürecine dâhil eder (Johnson, 2014; Patton, 2014). Eylem araştırması problemleri çözme ve gelişim kaydetmeye yönelik sistematik bir süreçtir. Daha çok bir problemi etkili ve uygulanabilir bir şekilde çözme ile ilgilenir (Tomal, 2010). Eylem araştırmalarında öğretmenler dışarıdan bakan birine göre sınıfları hakkında olay ve olgulara yönelik daha çok bilgiye sahip olmalarından hareketle araştırma planlayan ve uygulayan olabilirler (Kuzu, 2009; Tomal, 2010). Araştırmada öğretmen tarafından problem durumu olarak "aile içinde fiziksel şiddetin varlığı” konusu tespit edilmiştir. Daha sonra öğretmen araştırmacı rolünü üstlenerek ortaya çıkan problem durumunu çözmek amaçlı eylem planı oluşturup uygulayıcısı olarak eylem araştırması döngüsünü hayata geçirmiştir.

\section{Veri Toplama Araçları}

Araştırmada veri toplama aracı olarak görüşmeler, eğitim semineri değerlendirmeleri ve katılımcı güncelerinden faydalanılmıştır. Çalışmada kullanılan tüm veri toplama araçları Türkçe dilinde hazırlanmış ve uygulanmıştır. Bu araçlar çalışmanın amacı doğrultusunda çocukların istenmeyen davranışları karşısında annelerin ve çocukların algılarını belirlemek ve bunun sonucunda eylem planı basamaklarını uygulamak amacıyla kullanılmıştır. Çalışmada görüşmeler sırasında kullanılmak üzere yarı yapılandırılmış görüşme soruları araştırmacı tarafından hazırlanmıştır. Bu sorular uzman görüşü alınıp düzeltmeler yapıldıktan sonra uygulamaya hazır hale getirilmiştir. Görüşmeler ses kayıt cihazı ile kaydedilmiştir. Görüşme soruları anneler için dokuz, çocuklar için altı sorudan oluşmuş annelerin ve çocukların istenmeyen davranışla ilgili algılarını ortaya çıkarma amacıyla açık uçlu olarak hazırlanmıştır. Bu sorular çalışmanın başında mevcut durumun ve problemin belirlenmesi amacıyla; çalışmanın sonunda ise katılımcıların algılarındaki değişimi görmek amacıyla kullanılmıştır. Görüşmeler yaklaşık olarak 15-20 dakika sürmüştür. Eğitim semineri değerlendirme dokümanı her seminer sonrasında annelere sunulmuştur. Bu veri toplama aracı kazanımların belirtildiği ve yaşantılar ile seminerdeki konuların ilişkilendirildiği dört açık uçlu sorudan oluşmaktadır. Bir diğer veri toplama aracı olan katılımcı güncelerinde annelerden hem istenmeyen davranışı önleyici uygulamaları hem de istenmeyen davranış oluştuktan sonra verdikleri tepkileri yazmaları istenmiştir. Katılımcı günceleri için çocukların anneleri ile uzun süre birlikte olduğu ara tatil süreci kullanılmıştır.

\section{Çalışma Grubu}

Araştırmanın katılımcıları, Mersin ili Anamur illçesi Fatih illkokulu okul öncesi sınıfına kayıtlı araştırmacının öğrenci ve annelerinden oluşmaktadır. Bu amaçla 20 katılımcı ile görüşülmüş, araştırmaya gönüllü 12 anne ile başlanmıştır. Ancak sağlık, iş mazereti ve çalışmanın kendisi için gereksiz olduğu düşüncesi nedeniyle çalışmanın çeşitli aşamalarında ayrılan anneler olmuştur. Bu durumda çalışmaya 
katılmaya gönüllü sekiz anne ile araştırma tamamlanmıştır. Çalışma grubunun seçiminde bilgi yüklü durumları stratejik ve amaçı olarak belirlemeye dayalı olan amaçlı örneklem yöntemi kullanılmıştır. Amaçlı örneklem çeşitlerinden zaman, para ve çaba tasarrufu yapmak için tercih edilen uygun örneklem kullanılmıştır. Katılımcılar Mersin ili Anamur ilçesinde merkez ve merkez köylerde yaşayan sekiz anneden oluşmaktadır. Annelerin bir tanesi hemşire, üç tanesi sezonluk tarla iş̧̧isi olarak çalışmaktadır, dört anne ise ev hanımıdır. Annelerin yaşları 28 ile 42 arasında değişmektedir. Annelerin yedisi ilçe merkezinde biri de merkez köyde ikamet etmektedir. Annelerin dördü üç, dördü de iki çocuğa sahiptir. Annelerin eğitim düzeyine bakıldığında iki anne lise mezunu, iki anne orta öğrenim, dört anne ise ilkokul mezunudur. Çocuklar okul öncesi eğitim kurumuna devam eden 60-72 ay arası 5 erkek 3 kız öğrenciden oluşmaktadır.

\section{Verilerin Toplanması}

Annelerin çocuğun istenmeyen davranışlarına yönelik algılarını eylem planı öncesi ve sonrası incelemek amacıyla yapılan bu araştırmanın veri toplama süreci eylem araştırması birinci döngü tamamlanana kadar devam etmiştir. Bu doğrultuda veri toplama süreci; mevcut durum ve problemin belirlenmesi, eylem planı öncesi yaşantıların alınması, eylem planı süreci ve eylem planının değerlendirilmesinden oluşmaktadır. Verilerin toplanma süreci okulların açıldığı 2018 yılı Eylül-Ekim aylarında mevcut durum ve problemin belirlenmesi aşaması ile başlamış olup, Nisan ayında katıımcı değerlendirme görüşmesi ile son bulmuştur.

\section{Eylem Araştırması Süreci}

Araştırma mevcut durum ve problemin belirlenmesi aşaması ile başlamış olup, katııımcı değerlendirme görüşmesi ile ilk döngü tamamlanarak son bulmuştur. Eylem araştırması süreci bir problem ve çalışma konusu belirleme ile başlamaktadır. Bu süreç veri toplamak için plan yapmak, verilerin toplanması, analizi, düzenlenmesi, verilerin rapor edilmesi, yargı ve önerilerin sunumu, eylem planı yapmak, yapılan eylem planının uygulanması ve değerlendirilmesi basamaklarından oluşmaktadır. Çalışma sürecinde ilk olarak annelerin çocukla etkileşiminde istenmeyen davranışlara karşı algıları alınmış, sonrasında eğitim seminerlerinde belirtilenleri kendi yaşantıları ile karşılaştırarak değerlendirmeleri istenmiştir. Verilen eğitimlerin yaşantılarına yansımalarını görmek amacıyla günceleri alınmıştır. Bunun için çocukla yoğun etkileşim yaşadıkları ara tatil dönemine denk gelen 15 günlük süre değerlendirilmiştir. Son olarak çocukta görülen istenmeyen davranışla ilgili algıları tekrar alınmış ve tüm süreci değerlendirmeleri istenmiştir.

Annelerin istenmeyen davranışlar karşııında fiziksel şiddeti kullanma problemini araştırmacının fark etmesi ile mevcut durum ve problemin belirlenmesi süreci başlamıştır. Bu ilk tespitin ardından günlük eğitim akışı süreci boyunca yapılan gözlemler ve iletişimlerde, çocuklar anneleri ile ilişkilerinde istenmeyen bir durum yaşandığında sürekli ceza aldığını ve ceza olarak da fiziksel şiddet uygulamalarına maruz kaldıklarını ifade etmişlerdir. Çocuğun istenmeyen davranışlarında anneleri özellikle fiziksel şiddetin sınıf genelinde bu kadar yaygın kullanılıyor olması çözülmeyi bekleyen bir problem olduğunu düşündürmüştür. Sınıf içinde çocuklar ve öğretmen (araştırmacı) arasında geçen bir iletişim şöyledir: Araştırmacı tarafından dönem başında sınıf kurallarını oluşturma amaçlı çocuklara "kurallara uymazsak ne olur" diye sorulduğunda çocuklar "ceza alııı" diyerek evde yaşadığı deneyimlerden bahsetmeye başladılar; "Annem odamı toplamazsam oda cezası verir. Evde top oynarsam annem dövüyor. Annemin çubuğu var"

Mevcut durum ve problemin belirlenmesi aşamasında bir diğer veri toplama süreci de çocuğun istenmeyen davranışlarına yönelik algılarını öğrenebilmek üzere hazırlanmış yarı yapılandırılmış görüşme sorularının uygulanmasıdır. Sorular anne ve çocuklara ayrı olarak yöneltilmiştir. Bu süreçler ses kayıt cihazı ile kaydedilmiştir. Bu görüşmelerin analizi sonucunda bir sonraki adım olan eğitim seminerleri sürecinin başıkları ve içerikleri belirlenmiştir. Mevcut durum ve problemin belirlenmesi aşamasında edinilen bilgiler ışığında annelerin ihtiyacı olduğu konularda araştırmacılar tarafından eğitim sunuları hazırlanmıştır. Daha sonra oluşturulan seminer süreci annelerle birlikte belirlenen gün ve saatlerde uygulanmıştır. Aralık ayı içerisinde beş oturum olmak üzere hazırlanan bu eğitimler, benzer konular birleştirilerek her hafta bir seminer olmak üzere araştırmacı tarafından sunulmuştur. Karşılıkı etkileşim 
KURT, Dikici SIĞIRTMAÇ, ÖZSEZER - Çukurova Üniversitesi Eğitim Fakültesi Dergisi, 50(2), 2021, 1184-1209

ile yürütülen seminer süreçleri kamera ile kaydedilmiştir. Her seminer sonrası seminer hakkındaki görüşleri ve seminerde anlatılanlarla yaşantılarını ilişkilendirmeleri istenen katılımcı değerlendirmeleri alınmıştır. Aldıkları eğitimlerin yaşantılarına yansıyıp yansımadı̆̆ını belirlemek için uygulama günceleri oluşturulmuştur. Eğitim sonrası ara tatilin gelmesi ile beraber annelerin çocuklarla daha yoğun etkileşimde olacağı düşünülmüştür. Bu nedenle yaşadıkları istenmeyen davranışların oluşum nedenleri ve verdikleri tepkilere yönelik yaşantılarını yazmaları istenmiştir. Annelerin bu notları uygulama günceleri olarak kaydedilmiştir.

Son adımda sürecin katılımcılar tarafından değerlendirilmesi amacıyla mevcut durum ve problemin belirlenmesi sürecinde yöneltilen yarı yapılandırılmış sorular tekrar kullanılarak görüşme yapılmıştır. Ayrıca bu görüşme sonunda annelerin eylem planı sürecini değerlendirmeleri istenmiştir. Böylece eylem planının birinci döngüsü tamamlanmıştır. Eylem araştırması süreci ile toplanan verilere yönelik süreç Tablo 1'de belirtilmektedir.

Tablo 1

Veri Toplama Süreci

\begin{tabular}{lll}
\hline Etkinlik & Tarih/Süre & İçerik \\
\hline Mevcut Durum ve & Eylül-Ekim & Araştırmacı ve çocuk etkileşimi notları, \\
Problemin Belirlenmesi & & Annelerin bilgilendirilmesi ve davet edilmesi \\
& & Anne ve çocuklara görüşme yapılması
\end{tabular}

Eylem Süreci (Aralık)

\begin{tabular}{|c|c|c|}
\hline Oturum 1 & $30 \mathrm{dk}$ & $\begin{array}{l}\text { "Ceza, fiziksel şiddet ve çocuk üzerine etkileri" konulu } \\
\text { seminer verilmesi }\end{array}$ \\
\hline Oturum 2 & $25 \mathrm{dk}$ & $\begin{array}{l}\text { "Dünyada çocuklara yönelik fiziksel şiddet ve etkileri" } \\
\text { konulu araştırma sonuçları hakkında sunum }\end{array}$ \\
\hline
\end{tabular}

Oturum1/2 sonrası katılımcı değerlendirmesi

\begin{tabular}{|c|c|c|}
\hline Oturum 3 & $45 \mathrm{dk}$ & $\begin{array}{l}\text { 'Çocuk Hakları' ve dünyada çocuğa ceza olarak fiziksel } \\
\text { şiddetin önlenmesi konusunda son dönem politikaları }\end{array}$ \\
\hline \multicolumn{3}{|c|}{ Oturum 3 sonrası katılımcı değerlendirmesi } \\
\hline Oturum 4 & $45 \mathrm{dk}$ & Çocuk-ebeveyn etkili iletişim becerileri \\
\hline Oturum 5 & $45 \mathrm{dk}$ & $\begin{array}{l}\text { İstenmeyen davranışların ortaya çıkmasını engelleme ve } \\
\text { çocukları doğru davranışa yönlendirme teknikleri } \\
\text { sunumu } \\
\text { Çocuğa yönelik ceza-ödül ve etkili iletişim becerisi } \\
\text { konulu uzman görüşü videosu (Prof.Dr. Üstün Dökmen) }\end{array}$ \\
\hline \multicolumn{3}{|c|}{ 4.5. Oturum sonrası katılımcı değerlendirmesi } \\
\hline $\begin{array}{l}\text { Eğitim Sonrası } \\
\text { Katılımc1ların Alg1ları }\end{array}$ & Ara tatil & $\begin{array}{l}\text { İstenmeyen davranışların oluşum nedenleri ve tepkilerine } \\
\text { yönelik katılımcı günceleri }\end{array}$ \\
\hline Sürecin Değerlendirilmesi & $\begin{array}{l}\text { Mart ayı son } \\
\text { haftas1 }\end{array}$ & $\begin{array}{l}\text { Annelerle görüşme yapılması ve değerlendirmelerinin } \\
\text { alınması }\end{array}$ \\
\hline
\end{tabular}

\section{Veri Analizi}

Araştırmacı görüşmeleri sonuçlandırdıktan sonra kayıtların dökümü aşamasına geçmiştir. Araştırma sürecinde anne ve çocuklara uygulanan görüşme kayıtları dinlenmiş ve hiçbir değişiklik yapılmadan doğrudan yazılı kayda geçirilmiştir. Anne ve çocuklardan toplanan veriler yazılı hale getirilirken çocukların isimleri baş harfleri ile kodlanmış, anneler ise hangi çocuğun annesi ise yanına eklenmiştir $(H$ anne). Yazılı hale dökülen görüşme kayıtlarındaki veriler uzman görüşü de alınarak içerik analizi yoluyla analiz edilmiştir. Illk aşamada toplanan veriler sınıflandırılıp düzenlendikten sonra tamamı okunup incelenmiş, daha sonra verilerin aynı kategori içine alınarak düzenlenip temsili bir kelime yazma işlemi olan kodlamaları yapılmıştır (Creswell, 2014). Bu kategorilerin ifade edilmesine uygun temalar belirlenmiş ve kodlar, kategoriler ve temalar, inandırıcılık ilkesi için uzman bir kodlayıcının görüşüne sunulmuştur. Nitel araştırmalarda geçerlik ve güvenirliğin sağlanmasında analiz sürecinde ortaya çıkan öznellik riskini azaltmak için çoklu kodlama yapılır (Silverman, 2015). Bu nedenle çalışmada veri kodlama 
sürecine araştırmacı üçgenlemesi olarak da bilinen ikinci bir kodlayıcı katılmıştır. Böylece verilerin yorumlanmasının çapraz sorgusunun sağlanması amaçlanmaktadır. İi kodlayıcının uyumluluk düzeyi $\% 88$ olarak belirlenmiş ve kodlayıcılar tarafından farklı kodlar hakkında ortak karar verilmiştir (Barbour, 2001). Ayrıca araştırmanın geçerliliğini arttırmak için araştırmada izlenen süreç detaylı bir şekilde sunulmuş, yeterli miktarda ham veri bulgular kısmında yer almıştır. Düzenlemeler sonrasında kodlardan elde edilen 19 kategori ve 5 tema Tablo 2'de sunulmuştur.

Tablo 2

Birinci Eylem Planına Yönelik Temalar

\begin{tabular}{ll}
\multicolumn{1}{c}{ TEMALAR } & \multicolumn{1}{c}{ KATEGORILER } \\
\hline Cezaya Yönelik Çocuğun Algıları & Ceza Tanımlama \\
& Uygulanan Cezalar \\
& Ceza Nedeni \\
& Ceza sonrası Duygular \\
& Alternatifler \\
\hline Cezaya Yönelik Annenin Algıları & Ceza Tanımlama \\
& Uygulanan Cezalar \\
& Ceza Nedeni \\
& Ceza Sonrası Duygular \\
& Kabul Edilebilir şiddet \\
& Alternatifler \\
\hline Eğitimin Değerlendirilmesi & Eğitim sonrası ilk duygular \\
& Yaşantıyla eğitimin karşılaştırılması \\
& Geleceğe Yönelik Beklenti \\
\hline Eğitim Sonrası Uygulama Yaşantıları & \\
\hline & İstenmeyen Davranışın Nedenini \\
& Bulma \\
Cezaya Yönelik Eylem Planı Sonrası Annelerin Algıları & İstenmeyen Davranış Karşısında \\
& Uygulamalar \\
& Eğitimden Sonra Ceza Algısı \\
& Değerlendirme \\
\hline
\end{tabular}

\section{Bulgular}

Bu bölümde araştırmadan elde edilen bulgular; istenmeyen davranış karşısında fiziksel şiddet kullanımı yaşantıları hakkında annelerin ve çocukların algıları, eylem planının ilk döngüsünden sonra annelerin istenmeyen davranışlara ilişkin algıları ile annelerin eylem planı sürecine ilişkin değerlendirmeleri başlıkları altında verilmiştir.

\section{1- İstenmeyen Davranışa Karşı Fiziksel Şiddet Kullanımına Yönelik Çocukların Algılarını İçeren Bulgular}

Araştırmaya katılan öğrencilerin çoğu cezayı yaptıkları yanlış davranışın karşılığı olarak tanımlamışlardır: "Ablamın saçını yolduğumda" (A.S.) "Kötü bir şey yaptığımda bana ceza veriyorlar."(R) Çocukların birçoğu istenmeyen bir davranış yaptığında en çok annelerinin fiziksel şiddeti kullandığını ifade etmiştir. Çocukların bazıları da oyuncak toplama ve mola cezaları aldıklarını ifade etmişlerdir. Fiziksel şiddet cezası aldığını belirten bir çocuk yaşadıklarını şu şekilde dile getirmiştir "Dövüyor mesela koluma falan. Sonra başka bacağıma vuruyor. Başka cimcikliyor. Başka bir şey yok." (R). Ayrıca çocuklar annelerinin isteklerine itaat etmediği ve kardeşleri ile sorun yaşadığı durumlarda ceza aldıklarını şu ifadelerle belirtmiştir: "Kardeşimi ağlattığımda." (V) "Mesela annemden izinsiz yola çıksam, annemden izinsiz onun eşyalarını alsam, annemden izinsiz yola bardak götürsem." (H.A.) Araştırmada çocuklardan A.S. hariç hepsi annesi tarafından fiziksel şiddete maruz kaldığını ifade etmiştir. 
Araştırmada çocuklara annelerinin kendilerine yönelik ceza ve fiziksel şiddet uygulamaları neticesinde ne hissettikleri sorulmuştur. Çocukların hepsi üzüntü hissettiğini ifade etmiştir. Bir çocuk ek olarak kızgınlık, başka bir çocukta kötü hissettiğinden bahsetmiştir: "Ağlama yüzümde gözyaşları. (U) "Üzgün." (E) Çalışmada çocuklara annelerinin fiziksel şiddet yerine hangi tepkiyi verseler daha iyi olabileceği sorulduğunda birçoğu bu konuda fikri olmadığını ifade ederken, biri annesine yardım edebileceğini, bir başkası oturtması gerektiğini ve bir diğeri de odasını toplatabileceğini belirtmiştir: "Bilmiyorum. Dövmesini istemem. Bilmiyorum." (M.A.) "Bence ben ona yardım edeyim bana bir daha ceza vermez. Annemin kalbini alacam yani gönlünü alacam.". (H.A.)

1- İstenmeyen Davranışa Karşı Fiziksel Şiddet Kullanımına Yönelik Annelerin Algılarını İçeren Bulgular

Çalışmada annelerin ceza ile ilgili tanımlarına bakıldığında yaptırım, engelleme, suçun ya da yanlış davranışın karşılığı ifadelerinin tekrarlandığı belirlenmiştir. Bunun dışında kötü ama gerekli olduğu, itaat edilmediğinde başvurulduğu, durdurma ve fren anlamına geldiğini belirten tanımlar da yapılmıştır: "Ceza kötü bir şey bence. Çocuğun davranışlarına göre haline hareketine göre ona göre cezalandırman gerekiyor çocuğu. Benim düşüncem öyle yani."(B.anne) Çalışmada annelerin en sık kullandığı cezalar yoğunluk olarak sırasıyla fiziksel şiddet, mahrum bırakma, sözlü şiddet, sözlü uyarı, mola, tehdit ve küsme olarak belirlenmiştir. Annelerin bir tanesi hariç diğerleri fiziksel şiddeti kullandığını belirtmiştir. Mahrum bırakma annelerin yarısı tarafından en çok kullanılan diğer cezalandırma yöntemi olarak karşımıza çıkmaktadır: "Vuruyorum sadece başka bir ceza vermiyorum. Mesela çok kızıyorum kızdırıyorlar. Evet bağırıyorum. Odanıza gidin dediğim zaman gitmezler mesela öyle ceza versem gitmiyorlar." (M.A. anne) Annelerin kullandığı cezayı neden tercih ettiği sorulduğunda birçoğu rastgele kullandığı, belli bir sistematiği olmadığını belirtmiştir. Bazıları da o anki ruh hali gereği cezayı uyguladığını ya da yaptığı yanlış davranışa göre ceza belirlediğini söylemiştir. Bir anne ruh halinin uyguladığı cezada belirleyici olduğunu şu cümlelerle anlatmıştır: "Valla bağırdığım zamanlarda oluyor. Benim psikolojimle ilgili. Ama bu aralar genelde sakinim."(A.S. anne). Diğer bir anne ise çocuğun yanlış davranışının kendinde yarattığı etkiye göre ceza verdiğini şu ifadelerle anlatmaktadır: "Yaptığı davranışa göre değerlendirebiliyoruz. Yok çok ufak şeylere değil yani hani büyük bir kendine aşmış şeyleri yapmışsa o anlamda yani." (R. anne)

Katılımcı anneler çocuğun sorumluluklarını yerine getirmeme, (dağıttığı eşyayı toplamama) annenin isteklerini yerine getirmemesi nedeniyle cezalandırmayı tercih ettiklerini belirtmişlerdir. Diğer anneleri ceza vermeye iten nedenler eşyalara zarar verme, kardeşe şiddet, ısrarcı olma olarak ortaya çıkmıştır. Annelerden biri ise tahammülsüz olduğu için (A.S. anne) ceza verdiğini belirtmiştir: "Sözümü tutmadığı zaman, yapma dediğin bir şeyi aksine koyup yaptığı zaman, o şekilde. Onu da E çok yapıyor ya okulda da mı aynı bilmiyorum ama o şekilde yani. Mesela beni dinlemeyip de bir şeyi yap, getir deyip de getirmediğinde onu üstüne koyduğu zaman, mesela bir şeyi alıpta attığı zaman o durumlarda yapıyoruz. Sürekli konuşuruz da."(E.anne) Çalışmada annelerin biri hariç hepsi çocuklarına davranış değiştirme yolu olarak fiziksel şiddet uyguladığını ifade etmiştir: "Oldu yani yalan söyleyemem yani. Poposuna ellerine yani. Yüzüne de vurdum canım şimdi eskiden yani,"(A.S.anne) Çalışmaya katılan anneler fiziksel şiddeti nadiren kullandığını ifade etmiştir. Katılımcılardan ikisi ise sürekli olarak fiziksel şiddet uyguladığından bahsetmiştir: "Olduğu da oluyor. Valla terliği pata küte her tarafına vuruyorum yani küçüklerde dahil buna." (H.A.anne) Araştırmada annelerin çoğu uyguladıkları şiddeti makul ölçüde olduğunu gösteren "arada-sırada, sadece ellerine, sadece poposuna, hafifçe ve belli yerlerine" ifadelerini sıkça kullanmışlardır: "Ya hafifçe vururum. Ya şöyle vururum mesela koluna bacağına hafif bir şekilde." (V.anne) "Yani olmuştur itiraf edeyim bazen. Yani çok az bir şey böyle hafif bir şekilde annemin terliği oluyor ya o." (R. anne)

Çalışmaya katılan anneler şiddeti kullandıktan sonra çocuğun ve kendisinin neler hissettiği konusunda fikir birliği sağlamıştır. Fiziksel şiddeti kullanan annelerin hepsi çocukların üzüldüğünü ve kendilerinin de pişmanlık hissettiğini ifade etmişlerdir: "Üzülüyor. Anne sen beni sevmiyor musun? diyor mesela. Sonra bende pişman oluyorum. Niye yaptım? Niye vurdum? Vurmasaydım öyle."(M.A anne). Katılımcı annelerin çoğu olumlu davranış değiştirme yöntemlerini bilmediklerini belirtmişlerdir. 


\section{2- Annelerin Eylem Planı Sonrası İstenmeyen Davranışla Mücadele ile ilgili Algılarına ilişkin Bulgular}

Annelerin verilen seminerler sonrasında açık uçlu sorular aracılığıyla seminerler hakkında değerlendirmeleri alınmıştır. Bu değerlendirmelerde annelerin en çok kendi yaşantıları üzerinden pişmanlıkları ve şiddet algılarındaki yanlışlıklarını fark etmeleri göze çarpmıştır. Bir anne uyguladığı fiziksel şiddetin çocuğa etkilerine yönelik şu ifadeleri kullanmıştır: "Ben ufak şekilde vuruyordum onu şiddet sanmıyordum ama şiddetmiş. Çocuklarımızın da hakkı varmış onu öğrendik. Çocuğuma verdiğim zarar için üzgün hissettim. Çocuğun haklarını ben hiç bilmiyordum ama varmış ona bu hakkı vermediğim için üzgünüm." (Uanne). Diğer bir anne çocukları ile olan iletişimlerini düşünerek yaptığı karşılaştırma sonucu düşüncelerinde seminerin yarattığı etkiyi şu cümlelerle anlatmıştır: "Çok yanlışlarım olduğunu ve bunları nasıl giderebileceğimi anladım. Çocuklarıma utangaç bunlar demekle onları daha da utangaç içine kapanık demekle onları kötü olumsuz etkilediğimi öğrendim." (M.A anne)

Anneler çocuklarının yapmak istemediği davranışları yapması durumunda uyguladıkları yöntemlerde, tutarlı ve kararlı olma konusundaki eksikliklerini belirtmişlerdir. Davranış sonucunda ne tepki vereceklerine odaklandıklarını ama davranışın nedenleri üzerine sorgulamadıklarını bir anne şu cümlelerle ifade etmiştir. "Kardeşine vurduğunda direkt ceza yerine önce konuşup, nasıl niçin yaptığı sorulmalı. Çözüm bu çerçevede olmalı. Davranışlarımızda tutarlı olacağız. Okuldan gelince üstünü çıkarmıyor, üstünü çıkart yerine (emir kipi ile değil) üstünü çıkartırsan beni mutlu edersin gibi sözler kullanacağım. Ben dili kullanacağım." (H.A anne) Anneler değerlendirmelerinde seminerde vurgulanan şiddete alternatif davranış değiştirme yöntemlerinden bahsetmiş bu konuda kendi uygulamalarını değiştirmeye çabalayacakların belirtmişlerdir: "Ceza ve disiplin arasındaki farkı öğrendim. Çocuğumuzu disipline ederken en etkili ve faydalı yöntemin demokratik yöntem olduğunu öğrendim. Çocuğumla nasıl iletişim kurmamız gerektiğini ve onu nasıl dinlememiz gerektiğini ögrendim. Sen dili ve ben dilini öğrendim. Ben dilinin iletişimde ne kadar etkili olduğunu öğrendim. Empatinin önemini hatırladım. Çocuğumla ben diliyle iletişim kurmaya çalışacağım. Onu gerçekten dinleyeceğim." (A.S. anne) Anneler seminerde anlatılanları kendi çocukları ile etkileşimler bağlamında değerlendirildiğinde emir ifadesi yerine konuşma, çocuğu dinleme ve ödüllendirme konularına vurgu yapmış, yaşantısı ve anlatılanlar arasındaki farklılıkları belirtmiştir: "Ben çocuğumu hep bir şey alarak ödüllendiriyordum ama bunu sevgiyle yapmak yetiyormuş bunu anladım." (U anne).

Anneler kendi yaşantılarına yönelik çocuğun istenmeyen davranışları karşısında yapabilecekleri konusunda planlamalarını özellikle tutarııık ve kararlıık vurgusu yaparak ele almışlardır: "Bundan sonraki dönemlerde devamlıı̆̆ olan, tutarlı ve kararlı davranışlar göstermeye çalışacağım. Çocuğuma yeterince vakit ayırmadığımı fark ettim doğru iletişim kurmadığımı öğrendim." (A.S anne) iletişimin, manevi ödüllendirmenin ve daha çok birlikte vakit geçirmenin önemini bir anne şu cümlelerle belirtmiştir: "Mutlaka ödüller manevi olacak. Empati kuracağız. Çocuğumla daha çok iletişime geçeceğim." (H.A anne). Annelerin çoğu iletişim konusundaki yanlış tutumlarından yola çıkarak yapmayı düşündüğü değişimlerin ben dili, konuşma ve sevgiyle yaklaşma olduğunu belirtmişlerdir. Bir anne iletişim konusundaki yaşantılarını şöyle dile getirmektedir: "Genel olarak sen dili kullanıyoruz. Bunu ben diline çevirmeli. Çocuğumla iletişime daha fazla önem vereceğim." (R anne)

Annelerden çocukla daha sık vakit geçireceği ara tatil süresince çocuklarla etkileşimlerinde istenmeyen davranışın olası nedenlerini bulmaya çalışmaları ve bunları günceler aracılığıyla yazmaları istenmiştir. Bu güncelerde istenmeyen davranışın oluşumunda başlıca; kardeş kıskançlığı, eşyalarını toplamak istememe, dikkat çekmek isteme, sınırsız imkân isteme nedenlerinin etkisi olduğu ortaya çıkmıştır: "Çocuğum bu davranışı istediği şeyler olmayınca gösteriyor. Bunun sebebi istediği her şeyi yapmamız."(B anne) Annelerin ara tatil boyunca yazdığı güncelerde seminerde anlatılanlar ışığında çocukların istenmeyen davranışları karşısında uygulamalarını ifade etmeleri istenmiştir. Annelerin ifadelerine bakıldığında özellikle ben dilinin ve çocukla oynamanın davranış değişikliğinde etkili olduğu belirtilmiştir: "Üzerinden çıkardıklarının her birini bir köşeye atıyor. Eğer kıyafetlerini toplamazsan ben 
çok üzülüyorum ve sana ayıracak zamanımı kıyafet toplayarak geçireceğim deyince artık bakıyorum toplayıp dolabina koyuyor." (H.A anne).

Annelerin istenmeyen davranışlar karşısında uygulamaları hakkında algılarını ortaya koymak için tekrar görüşmeler yapılmış ve süreci değerlendirmeleri istenmiştir. Anneler ceza tanımlamasını, arzu edilmeyen davranış sonucunda yapılan uygulamalar olarak ifade etmişlerdir. Belli durumlarda bu uygulamaları kullandıklarını belirtmişlerdir. Annelere çocuğun istenmeyen davranışında nasıl bir tutum sergilediği sorulduğunda annelerin birçoğu eskiden vurduklarını şimdi konuşmaya ve düşünmesini sağlamaya özen gösterdiklerini ifade etmişlerdir: "Eskiden vuruyorum diyordum ya o günden sonra sabrettim vurmamaya başladım. Onun yerine düşünelim niye bu yaptığın şeye üzüldüm ben diyorum" (V.anne). Ayrıca anneler seminerde anlatılan davranış değiştirme yöntemlerinden bazılarını uyguladıklarını ifade etmişlerdir: "Önceden paspasa yollardım direk şimdi önce uyarıp konuşuyorum. Uyarıyorum ufak şeylerde kendine kardeşine zarar olur."(U anne) Anneler seminerde anlatılan davranış değiştirme yöntemlerinden en çok konuşma ve düşünmeye gönderme yöntemini kullandıklarını şu ifadelerle anlatmıştır: "iç̧eri yolluyorum. Bakıyorum. Oluyor yani. Sarılıyor özür diliyor. Bide konuşuyorum bol bol. Üzülüyorum diyorum. Bak şöyle olur böle olabilir diyorum." (E anne)

\section{3- Annelerin Eylem Planı Sürecini Değerlendirmelerine Yönelik Bulgular}

Anneler seminerlerde verilen eğitimlerin algılarındaki olumlu etkilerden bahsederken çocuğa fiziksel şiddet uygulamanın hem çocuk hem de kendileri için olumsuz sonuçlanacağını belirtmişlerdir: "Anladım çocuğun ne kadar olumsuz etkileneceğini. ilerde kendi çocuklarına uygulayacak sinirli olacak yani. Fiziksel şiddetin azı-çoğu olmadığını konunun ciddiyetini hissettim. Çocuğuma vurduğum anları hatırlayıp üzüldüm" (A.S anne). Ayrıca yıkıcı etkileri olan bağırmak ve fiziksel şiddet uygulamak gibi yöntemler yerine eğitimlerde verilen konuşma, olumlu iletişim ve sorunu çözmeye çalışmaya yönelik yöntemleri uygulamaya çalıştıklarını belirtmişlerdir. Bir anne ise eskiye göre daha çok zaman ayırıp çocuklarla oynamaya başladığını, evin içinde birlikte etkileşimi sağlayacak vakit geçirici aktiviteler yaptığını ve çevrenin bozulma ve dağılması konusunda artık kaygılanmadığını ifade etmiştir: "Önce beni çok sinirlendirdiğinde çıldırır kızardım şimdi yumuluyorum üstüne öpüyorum gıdıklıyorum. Önceki terlik şimdi yok boğuşuyorum. Konuşuyorum. Düşünüyorum bağırdığım şeylere saçma sapan şeylermiş ya. $O$ dağıtma şeyini geçtim akşam mesela kek yaptık dök oğlum kabartma tozunu. Hoşlarına gidiyor. Dağılsın onlar uyuyunca 1 saatte toplanır zaten."( $H$ anne)

Annelere yapılan çalışma hakkında neler düşündüğü sorulmuş ve kendileri için etkililiğini değerlendirmeleri istenmiştir. Annelerin çoğu yapılan çalışma ile ilk kez karşılaşı̆ı̆ını ve çok faydalı olduğunu, bu gibi eğitimlerin sık sık yapılması gerektiğini, sık olmasının kendileri için hatırlatıcı olduğunu ifade etmişlerdir. Bazı annelerde bu eğitimlerin babalar içinde verilmesi gerektiğini belirtmişlerdir: "Bu tür eğitimler sık sık yapılmalı. Öneririm ben, unuttuğumuz oluyor. Hatırlatmalı gündemde tutulmalı. Babalar katılabilir kesinlikle. Eşim bazen vuruyor." (A.S anne). Annelerden biri aynı bina içinde büyük anne, büyük baba ve amcalarla birlikte yaşadıklarını ve bu aile büyüklerinin yanlış müdahalelerde bulunarak özellikle kurallara uyma konusunda çocuğun gelişimini olumsuz etkilediğini belirtmişlerdir: "Diyorum kararlı olayım ama çocuk destek alıyor onlardan. Hemen yanlarına yukarı kaçıyor. Onlara anlatıyorum, ama yok. Çocuk babaanneyi görünce anne baba hiç oluyor."(B anne)

\section{Tartışma ve Sonuç}

Bu araştırmada annelerin çocukların istenmeyen davranışları ile mücadelede fiziksel şiddeti kullandığı sonucuna ulaşılmıştır. 2010 yııında 7-18 yaş arası 1.886 çocuk ile yürütülen aile içi şiddeti de konu alan çalışmada çocukların \%45'inin fiziksel ceza ile cezalandırıldı̆̆ı tespit edilmiştir (Müderrisoğlu, Dedeoğlu, Akço ve Akbulut, 2014). Belon (2014) fiziksel cezanın bireyler tarafından tanımlanması, kuşaklar arası iletimi, aile ile ilişkilerde ve psikolojik-duygusal iyi olma durumuna etkisini incelediği çalışmasında, katılımcıların \%60'ı fiziksel cezaya karşı olduğunu belirtirken, \%70'i özellikle şaplak kullandığını belirtmiştir. Bu cezaların birçoğunun da koluna vurmak ve çimdiklemek gibi eylemleri içeren cezalar olduğu belirlenmiştir. Yapılan çalışmalar her 3-5 yaş arası üç çocuktan birinin şiddet mağduru olduğunu ebeveynler içinde en çok annelerin çocuklarına fiziksel şiddet uyguladığını ortaya koymaktadır. Bunun nedeni olarak da annelerin çocukları ile daha çok vakit geçirmesinden dolayı anneler tarafından 
çocukların şiddet mağduru olma olasılıklarının daha yüksek olduğunu belirtmişlerdir (Chan, 2012; Wauchope ve Straus, 2017).

Bu çalışmada anneler çocuklara uyguladığı disiplin yöntemi olarak fiziksel şiddeti tanımlarken; hafif̧̧e ellerine, poposuna yavaşça gibi fiziksel cezayı uygulanabilir düzeyde gösterme amaçlı ifadeler kullanmışlardır. Yapılan bazı çalışmalarda da ebeveynlerin kullandıkları bedensel ceza yöntemlerini örtbas etmek için hafif ve sıradan gibi basit ifadeler kullandıkları görülmüştür (Ateah ve Durrant, 2005; Fréchette ve Romano, 2017). Çalışmamızda anneler nadiren ve arada sırada fiziksel şiddet kullandığını belirtirken, çocuklar istenmeyen davranışlarında annelerinin vurma, çimdikleme, saç çekme, sıkıştırma şeklinde fiziksel şiddet kullandıklarını ifade etmiştir. Bu durumun nedeni ya annelerin yanıtlarının doğruyu yansıtmaması ya da fiziksel şiddetin bıraktığı etki nedeniyle çocuk tarafından sürekli dile getirilmek istenmesi olabilir. Yapılan çalışmalarda iki-dört yaş arasındaki çocukların ebeveynleri tarafından sırasıyla en sık şaplak, çimdikleme, saç çekme, kemer/kordon/çubuk gibi araç kullanma şekillerinde fiziksel şiddet uygulamasına maruz kaldığı sonucuna ulaşılmıştır (Bell ve Romano, 2012; Fréchette ve Romano, 2017; Straus, 2010; Zolotor ve Puzia, 2010). Çalışmamızda annelerin fiziksel şiddet tercihlerinin belirleyicilerine bakıldığında birçoğunun rastgele kullandığı, bazılarının da o anki ruh halinin etkili olduğu ya da çocuğun yaptığı yanlış davranışa göre seçim yaptığı ortaya çıkmışır. Yapılan bir çalışmada benzer olarak annenin bilişsel ve duyuşsal özelliklerinin fiziksel cezayı çocukta kullanma kararında etkili olduğu sonucuna ulaşılmıştır (Ateah ve Durrant, 2005). Ayrıca çalışmalar fiziksel cezanın kullanılabilirliğine yönelik inanç düzeyleri ile fiziksel çocuk istismarı potansiyeli arasında pozitif bir ilişki ortaya koymuştur. Fiziksel cezaya karşı yüksek bir inanç beyan eden ebeveynlerin ebeveynlik stresinin yüksek olduğu çalışmaların diğer sonuçlarındandır (Bardi ve Borgognini-Tarli, 2001; Cappa ve Khan, 2011; Crouch ve Behl, 2001; MacKenzie ve diğerleri, 2013; Taylor ve diğerleri, 2016). Mevcut çalışmada annelerin çocuğun sorumluluklarını (dağıttığı eşyayı toplamama) ve annenin isteklerini yerine getirmemesi nedeniyle cezalandırmayı tercih ettikleri ortaya çıkmıştır. Anneleri ceza vermeye iten diğer nedenler ise eşyalara zarar verme, kardeşe şiddet, ısrarcı olma olarak belirlenmiştir. Alan yazı incelendiğinde ise annelerin uyguladığı fiziksel ceza kullanım nedenleri; annenin çocuğun davranışını uygun bulmaması, fiziksel cezaya karşı annelik tutumu, çocuğun yanlış davranışının ciddiyet ve niyetine ilişkin annenin algısı ve çocuğun yanlış davranışına tepki olarak annenin öfkesi olarak sıralanmıştır (Ateah ve Durrant, 2005; Taabur, 2015 Taylor ve diğerleri 2016; Winstok, 2014).

Araştırmamızda annelerin ceza ve fiziksel şiddet uygulamaları neticesinde çocukların üzüntü hissettikleri belirlenmiştir. Çocukların çok azı fiziksel şiddet yerine annesinin sorumluluk vermesinin doğru olacağını düşünmekte birçoğu ise alternatif disiplin yöntemlerini bilmemektedir. Ancak çocuklar istenmeyen bir davranış yaptıklarında anneleri tarafından fiziksel şiddete maruz kalmak istememektedir. Çalışmaya katılan annelerin de şiddet kullandıktan sonra üzüldüğü ve pişmanlık hissettiğ̈i ancak alternatif davranış değiştirme yöntemlerini bilmediği ortaya çıkmıştır. Benzer şekilde çalışmalar annelerin onaylamadığı ve uygun görmediği halde fiziksel cezayı kullandığını cezalandırıcı olmayan disiplin yöntemlerini bilmediklerini göstermektedir (Cappa ve Khan, 2011; Gagné, Tourigny, Joly ve PouliotLapointe, 2007; Romano, Bell ve Norian, 2013). Annelerin eğitimlerin hemen sonrasında yaptıkları değerlendirmelerinde pişmanlıklara ve yanlışıılara vurgu yaptıkları görülmüştür. Annelerin çocukla etkileşiminde istenmeyen davranışın nedenlerini sorgulamadığı ve davranış değiştirme amaçlı çocuğa şiddet uygulamanın olası sonuçları konusunda bilgi sahibi olmadığı ortaya çıkmıştır. Bu doğrultuda yapılan çalışmalar çocuk gelişiminde ebeveynlerin çocukla etkileşimlerinin verimliliğini arttırmanın önemi üzerinde durmakta ve sağıklı bir aile hayatı için anne-babalık gibi eğitimlerin gerekliliğini vurgulamaktadır (Bağatarhan ve Nazlı, 2013; Chavis ve diğerleri, 2013; Ersoy, Kurtulmuş \& Tekin, 2014).

Çalışmamızdaki güncelerde kardeş kıskançlı̆ı, eşyalarını toplamak istememe, dikkat çekmek isteme, sürekli bir şeyler isteme davranışları istenmeyen davranışlar olarak sıralanmıştır. Ayrıca anneler ev içi sorumluluklar ve iş hayatı nedeniyle çocukla çok fazla ilgilenemediklerini ve birlikte vakit geçiremediklerini ifade etmişlerdir. Alan yazın incelendiğinde ebeveyn tutumları ile çocukların davranışları arasında ilişki olduğunu ve ebeveynlerin çocuklarıyla ilgilenmemelerinin de çocukların davranış sorunları göstermesi ile sonuçlanabileceğini göstermektedir (Aydoğdu ve Dilekmen, 2016; Waller ve diğerleri, 2012; Yurduşen, Erol ve Gençöz, 2013). Mevcut çalışmada anneler istenmeyen 
davranış karşısında etkili iletişim becerileri kullanma (ben dili) ve istenmeyen davranışı oluşturacak ortamı engellemenin (çocukla oynama, alternatif etkinlikler sunma) çocukla etkileşimde işe yaradığına yönelik yaşantılarından betimlemeler yapmışlardır. Gordon (2001) sen dilinin vermek istediği temel mesajın, istenmeyen davranışa değil çocuğun kişiliğine-benlik saygısına yönelik olduğunu ifade etmektedir. Oysaki ben dili mesajları çocuğun istenmeyen davranışının etkilerine vurgu yapmaktadır. Ayrıca ebeveynleri dürüst ve çocukları ile anlamlı ilişkiler kurabildikleri gerçek kişiler olarak göstermekte ve yakınlı̆ı̆n gelişmesine yardım etmektedir. Çalışmamızda annelerin eğitimler sonundaki değerlendirmelerinde kendi uygulamalarını sorgulayarak, çocukla kullandıkları iletişim dili ve çocuğu dinlemenin önemini belirttikleri görülmüştür. Ayrıca katııımcların büyük kısmının yaptıkları yanlışları ve bilgi eksikliklerini tespit ettikleri, tutarlı ve kararlı olunması gerektiğini belirttikleri tespit edilmiştir. Alan yazı incelendiğinde yapılan çalışmalarda annenin tutarsız disiplininin çocukların dışsallaştırma davranışında artışa neden olduğu ve bir çocuğun dışa dönük davranışının, disiplinin tutarsızlığı yerine disiplin yöntemiyle daha fazla ilişkisi olabileceği sonucuna varılmıştır (Gryczkowski ve diğerleri, 2010; Keyes ve diğerleri, 2015).

Annelerin eğitim değerlendirmeleri ve ara tatil günceleri sonrası algılarına bakıldığında fiziksel şiddet yerine konuşmaya ve düşünmesini sağlamaya yönelik uygulamalara yoğunluk gösterdiği ortaya çıkmıştır. Ayrıca anneler istenmeyen davranışın oluşumunu engellemek için daha çok birlikte zaman geçirdiklerini ve anne-çocuk etkileşimlerini öncelikler arasına koymaya çalıştıklarını belirtmişlerdir. Benzer şekilde fiziksel ceza kullanan ebeveynler için yapılan müdahale programlarının sonuçlarına bakıldığında ebeveyn tutumlarının daha az fiziksel ceza kullanmaya doğru yönlendirilebileceği ve ebeveynlerin fiziksel ceza kullanmamaları gerektiğinin öğretilebilir olduğu sonucuna ulaşılmışır (Chavis ve diğerleri, 2013; Holden, Brown, Baldwin ve Caderao, 2014; Scholer, Hamilton, Johnson ve Scott, 2010). Katılımciların değerlendirmeleri ışığında eylem araştırması sürecinde yapılan seminer çalışmalarının anneler tarafından geliştirici olduğu ancak daha sık tekrarlanması gerektiği sonucuna ulaşılmıştır. Yapılan araştırmalara baktığımızda da ebeveyn eğitim ve destek programlarının hem çocukların gelişimi üzerindeki olumlu yönde etkilerini inceleyen hem de ebeveynlerin kişisel gelişimlerine katkılarının olduğunu gösteren çalışmalar mevcuttur (Bağatarhan ve Nazlı, 2013; Bekman ve Atmaca Koçak, 2011; Östberg, Hagekull, Lindberg ve Dannaeus, 2005; Ritter, 2003). Anneler çalışmanın kendileri için geliştirici olmasının yanında sadece anneler ile yapılmasını eleştirmiş, babalarında dahil edileceği çalışmaların sorun çözmede daha etkili olacağından bahsetmişlerdir. Bazı katılımcıların çocukla etkileşimlerinde aile büyüklerinin müdahalesinin istenmeyen davranışla mücadele etmede sorun yarattığını belirtmeleri çalışmanın bir diğer bulgusudur. Çalışmalar incelendiğinde büyükanne ve büyükbaba ile birlikte yaşamanın aile içi ilişkileri etkilediği ve bu ebeveynlerin çocuklara aşırı hoşgörülü davranmaları sonucu oluşan çocuktaki olumsuz davranışların önlenmesinde, anne ve babanın daha katı disiplinli olmak zorunda kaldığı görülmüştür (Özyürek ve Tezel Şahin, 2005; Yavuzer, 2003). Bu araştırmadan elde edilen bulgular doğrultusunda şu önerilerde bulunulabilir:

Çalışma sonuçlarına göre çocukların istenmeyen davranışları ile mücadele yaşantılarını geliştirmek için annelerin desteklenmesi gerekmektedir. Bu kapsamda öncelikle ebeveyn eğitimi konusunda ilgili lisans ve ön lisans programlarının içeriğinin güncellenmesi, yeni ve etkili yaklaşımların aileye ulaşmasına yardım edebilir. Çalışma bulgularında öğretmenin sınıf içi etkileşimler ile problem durumunu tespit ettiği görülmektedir. Bu kapsamda ebeveynlere yakın mesafede olan öğretmenlerin aile eğitimi ve katılımı konusunda intiyaçları belirlenebilir. Bu intiyaçlar doğrultusunda alan uzmanları tarafından konu başlıkları hazırlanıp hizmet içi eğitimler düzenlenebilir. Bu eğitimler aracılı̆̆ılla sık sık ebeveynle etkileşimi olan öğretmenlerin aile eğitimi ve katılımı konusunda becerileri geliştirilebilir. Bu eğitimler sonrasında her okul bünyesinde öğretmenler belli aralıklarla çocukla iletişimde istenmeyen davranışla mücadele yaşantıları konularında ihtiyaç analizi yaparak seminerler düzenleyebilir. Bu seminerlerin toplum genelinde uygulanması için yerel yönetimler ve politika düzenleyiciler teşvik edici girişimlerde bulunabilir. Üniversitelerden alan uzmanları bu seminerlere çağırılarak seminerlerin verimliliği arttırılabilir. Katılım düzeyleri düşük ebeveyn olan babaların eğitim süreçlerine katııımı için gereken koşullar üzerine çalışmalar yapılabilir. Bu eğitimlerin çocuğun farklı alanlardaki gelişimine etkisi ile ilgili 
KURT, DiKici SIĞIRTMAÇ, ÖZSEZER - Çukurova Üniversitesi Eğitim Fakültesi Dergisi, 50(2), 2021, 1184-1209

deneysel araştırmalar planlanabilir. Farklı yaş gruplarından çocuğu olan ebeveynlerin istenmeyen davranışla mücadele algılarına yönelik çalışmalar planlanıp sonuçlar karşılaştırılabilir.

Yayın Etiği: Bu araştırmada “Yükseköğretim Kurumları Bilimsel Araştırma ve Yayın Etiği Yönergesinde' yer alan tüm kurallara uyulmuş ve yönergenin ikinci bölümünde yer alan "Bilimsel Araştırma ve Yayın Etiğine Aykırı Eylemlerden" hiçbiri gerçekleştirilmemiştir.

\section{References}

Altafim, E. R. P., \& Linhares, M. B. M. (2016). Universal violence and child maltreatment prevention programs for parents: A systematic review. Psychosocial Intervention, 25(1), 27-38.

Altafim, E. R. P., Pedro, M. E. A., \& Linhares, M. B. M. (2016). Effectiveness of ACT raising safe kids parenting program in a developing country. Children and Youth Services Review, 70, 315-323.

Ateah, C. A., \& Durrant, J. E. (2005). Maternal use of physical punishment in response to child misbehavior: Implications for child abuse prevention. Child Abuse \& Neglect, 29(2), 169-185.

Aydoğdu, F., \& Dilekmen, M. (2016). Evaluation of parental attitudes in terms of various variables. Journal of Bayburt Faculty of Education, 11(2), 569-585.

Bağatarhan, T., \& Nazlı, S. (2013). The effect of parent education program on mothers' parenting selfefficacy. Journal of Social Policy Studies, 7(31), 67-88.

Barbour, R. S.(2001). Checklists for improving rigour in qualitative research: a case of the tail wagging the dog? British Medical Journal 322(1), 115-117.

Bardi, M., \& Borgognini-Tarli, S. M. (2001). A survey on parent-child conflict resolution: intrafamily violence in Italy. Child Abuse \& Neglect, 25(6), 839-853.

Bekman, S. ve Atmaca Koçak A. (2011). Mothers from five countries tell: The effects of the mother-child education program, Education and Science, 161,132-144.

Bell, T., \& Romano, E. (2012). Opinions about child corporal punishment and influencing factors. Journal of Interpersonal Violence, 27(11), 2208-2229.

Belon, S. (2014). Experiences of corporal punıshment. Dissertation Abstracts International, (UMI No.3620256)

Breen, A., Daniels, K., \& Tomlinson, M. (2015). Children's experiences of corporal punishment: A qualitative study in an urban township of South Africa. Child Abuse \& Neglect, 48, 131-139.

Cappa, C., \& Khan, S. M. (2011). Understanding caregivers' attitudes towards physical punishment of children: Evidence from 34 low-and middle-income countries. Child Abuse \& Neglect, 35(12), 10091021.

Chan, K. L. (2012). Comparison of parent and child reports on child maltreatment in a representative household sample in Hong Kong. Journal of Family Violence, 27(1), 11-21.

Chavis, A., Hudnut-Beumler, J., Webb, M. W., Neely, J. A., Bickman, L., Dietrich, M. S., \& Scholer, S. J. (2013). A brief intervention affects parents' attitudes toward using less physical punishment. Child Abuse \& Neglect, 37(12), 1192-1201.

Clément, M. Ė., \& Chamberland, C. (2014). Trends in corporal punishment and attitudes in favour of this practice: Toward a change in societal norms. Canadian Journal of Community Mental Health, 33(2), 13-29.

Coore Desai, C., Reece, J. A., \& Shakespeare-Pellington, S. (2017). The prevention of violence in childhood through parenting programmes: a global review. Psychology, Health \& Medicine, 22(sup1), 166-186.

Crouch, J. L., \& Behl, L. E. (2001). Relationships among parental beliefs in corporal punishment, reported stress, and physical child abuse potential. Child Abuse \& Neglect, 25(3), 413-419. 
KURT, Dikici SIĞIRTMAÇ, ÖZSEZER - Çukurova Üniversitesi Eğitim Fakültesi Dergisi, 50(2), 2021, 1184-1209

Creswell, J. W. (2014). Qualitative, quantitative research design and mixed method approaches (Trans. Ed. SB Demir). Ankara: Eğiten Book.

D'Souza, A. J., Russell, M., Wood, B., Signal, L., \& Elder, D. (2016). Attitudes to physical punishment of children are changing. Archives of Disease in Childhood, 101(8), 690-693.

Ersoy, Ö. A., Kurtulmuş, Z. ve Tekin, N. Ç. (2014). Investigation of the effect of family child education program on mothers' child-rearing attitudes and regulation of home environment. Kastamonu Journal of Education,22(3), 1077-1090.

Fréchette, S., \& Romano, E. (2017). How do parents label their physical disciplinary practices? A focus on the definition of corporal punishment. Child Abuse \& Neglect, 71, 92-103.

Gagné, M. H., Tourigny, M., Joly, J., \& Pouliot-Lapointe, J. (2007). Predictors of adult attitudes toward corporal punishment of children. Journal of interpersonal Violence, 22(10), 1285-1304.

Gardner, F. E., Sonuga-Barke, E. J., \& Sayal, K. (1999). Parents anticipating misbehavior: An observational study of strategies parents use to prevent conflict with behavior problem children. The Journal of Child Psychology and Psychiatry and Allied Disciplines, 40(8), 1185-1196.

Gershoff, E. T. (2013). Spanking and child development: We know enough now to stop hitting our children. Child Development Perspectives, 7(3), 133-137.

Gershoff, E. T., \& Grogan-Kaylor, A. (2016). Spanking and child outcomes: old controversies and new meta-analyses. Journal of Family Psychology, 30(4), 453.

Gordon, T.(2001). EPE (Effective Parent Education). İstanbul: Sistem Publishing.

Gryczkowski, M. R., Jordan, S. S., \& Mercer, S. H. (2010). Differential relations between mothers' and fathers' parenting practices and child externalizing behavior. Journal of Child Family Studies, 19, 539546.

Hillis, S. D., Mercy, J. A., \& Saul, J. R. (2017). The enduring impact of violence against children. Psychology, Health \& Medicine, 22(4), 393-405.

Hillis, S., Mercy, J., Amobi, A., \& Kress, H. (2016). Global prevalence of past-year violence against children: a systematic review and minimum estimates. Pediatrics, 137(3), e20154079.

Holden, G. W., Brown, A. S., Baldwin, A. S., \& Caderao, K. C. (2014). Research findings can change attitudes about corporal punishment. Child Abuse \& Neglect, 38(5), 902-908.

Humphreys, T. (2003). What is discipline and what is not? İstanbul: Epsilon Publishing.

Johnson, A. P. (2014). Action research handbook (Trans. Ed. Y. Uzuner and M.Ö. Anay).Ankara: Anı Publishing.

Keyes, K., Leray, E., Pez, O., Bitfoi, A., Koç, C., Goelitz, D., ... \& Fermanian, C. (2015). Parental use of corporal punishment in Europe: intersection between public health and policy. Plos One, 10(2), e0118059.

Khan, M., Quadri, S. M. A., \& Aziz, S. (2014). Association of family structure and its environment with aggressive behavior of children (6-8 years) in a rural community. Journal of Child Adolescents Behavior, 2, (125), 1-4

Knox, M., Burkhart, K., \& Cromly, A. (2013). Supporting positive parenting in community health centers: The ACT Raising Safe Kids Program. Journal of Community Psychology, 41(4), 395-407.

Kuzu, A. (2009). Öğretmen yetiştirme ve mesleki gelişimde eylem araştırması. Journal of International Social Research, 1(6), 425-433.

MacKenzie, M. J., Nicklas, E., Waldfogel, J., \& Brooks-Gunn, J. (2013). Spanking and child development across the first decade of life. Pediatrics, 132(5), e1118-e1125.

Maguire Jack, K., Gromoske, A. N., \& Berger, L. M. (2012). Spanking and child development during the first 5 years of life. Child Development, 83(6), 1960-1977. 
KURT, Dikici SIĞIRTMAÇ, ÖZSEZER - Çukurova Üniversitesi Eğitim Fakültesi Dergisi, 50(2), 2021, 1184-1209

Müderrisoğlu, S., Dedeoğlu, C., Akço, S. ve Akbulut, B. (2014). Domestic violence research for children aged 0-8 years old in Turkey. Bernard van Leer Foundation, Boğaziçi University, Humanist Bureau and Frequency Research: Istanbul.

Oas, P. T. (2010). Current status on corporal punishment with children: What the literature says. The American Journal of Family Therapy, 38(5), 413-420.

Österman, K., Björkqvist, K., \& Wahlbeck, K. (2014). Twenty-eight years after the complete ban on the physical punishment of children in Finland: Trends and psychosocial concomitants. Aggressive Behavior, 40(6), 568-581.

Östberg, M., Hagekull, B., Lindberg, L., \& Dannaeus, M. (2005). Can a child-problem focused intervention reduce mothers' stress?. Parenting: Science and Practice, 52, 153-174.

Patton, M. Q. (2014). Qualitative research and evaluation methods (Translation Editors: M. Bütün-SB Demir)Ankara: Pegem Yayıncılık.

Park, A. (2010). The long-term effects of spanking. Time Magazine. Retrieved from: https://www.casaverams.com/public/articles/stories/t-the-long-term-effects-of-spanking.pdf

Ritter, K. B. (2003). An exploration of mothers' perceptions of the value from attending an adlerian study group based on the active parenting today program Dissertation Abstracts International. (UMI No: 3110116).

Romano, E., Bell, T., \& Norian, R. (2013). Corporal punishment: Examining attitudes toward the law and factors influencing attitude change. Journal of Family Violence, 28(3), 265-275.

Scholer, S. J., Hamilton, E. C., Johnson, M. C., \& Scott, T. A. (2010). A brief intervention may affect parents' attitudes toward using less physical punishment. Family \& Community Health, 33(2), 106116.

Silverman, D. (2015). Interpreting qualitative data. Sage.

Simons, D. A., \& Wurtele, S. K. (2010). Relationships between parents' use of corporal punishment and their children's endorsement of spanking and hitting other children. Child Abuse \& Neglect, 34, 639646.

Stoltenborgh, M., Bakermans-Kranenburg, M. J., Van Ijzendoorn, M. H., \& Alink, L. R. (2013). Culturalgeographical differences in the occurrence of child physical abuse? A meta-analysis of global prevalence. International Journal of Psychology, 48(2), 81-94.

Straus, M. A. (2010). Prevalence, societal causes, and trends in corporal punishment by parents in world perspective. Law and Contemporary Problems, 73(2), 1-30.

Straus, M. A., \& Paschall, M. J. (2009). Corporal punishment by mothers and development of children's cognitive ability: A longitudinal study of two nationally representative age cohorts. Journal of Aggression, Maltreatment \& Trauma, 18(5), 459-483.

Taabur, T. (2015). Corporal Punishment by Parents. Dissertation Abstracts International, (UMI No. 1592036)

Taylor, C. A., Al-Hiyari, R., Lee, S. J., Priebe, A., Guerrero, L. W., \& Bales, A. (2016). Beliefs and ideologies linked with approval of corporal punishment: A content analysis of online comments. Health Education Research, 31(4), 563-575.

Taylor, C. A., Manganello, J. A., Lee, S. J., \& Rice, J. C. (2010). Mothers' spanking of 3-year-old children and subsequent risk of children's aggressive behavior. Pediatrics, 125(5), e1057-e1065.

Tomal, D.R. (2010). Action research for education (2nd ed.) Lanham, MD: Rowman \& Littlefield Publishers, Inc.

Waller, R.,Gardner, F., Hyde, L. W., Shaw, D. S., Dishion, T. J. ve Wilson, M. N. (2012). Do harsh and positive parenting predict parent reports of deceitful - callous behavior in early childhood? Journal of Child Psychology and Psychiatry, 53 (9), 946- 953. 
KURT, Dikici SIĞIRTMAÇ, ÖZSEZER - Çukurova Üniversitesi Eğitim Fakültesi Dergisi, 50(2), 2021, 1184-1209

Wauchope, B. A., \& Straus, M. A. (2017). Physical punishment and physical abuse of American children: Incidence rates by age, gender, and occupational class. In Physical violence in American families (pp. 133-148). Routledge.

Weymouth, L. A., \& Howe, T. R. (2011). A multi-site evaluation of parents raising safe kids violence prevention program. Children and Youth Services Review, 33 (10), 1960-1967.

Winstok, Z. (2014). Israeli mothers' willingness to use corporal punishment to correct the misbehavior of their elementary school children. Journal of interpersonal violence, 29 (1), 44-65.

World Health Organization. (2009). Preventing violence through the development of safe, stable and nurturing relationships between children and their parents and caregivers. World Health Organization. Geneva. Retrieved from: http://whqlibdoc.who.int/publications/2009/ 9789241597821_eng.pdf

Yurduşen, S., Erol, N. ve Gençöz, T. (2013). The effects of parental attitudes and mothers' psychological well-being on the emotional and behavioral problems of their preschool children. Maternal and Child Health Journal, 17(1), 68-75.

Zolotor, A. J., \& Puzia, M. E. (2010). Bans against corporal punishment: A systematic review of the laws, changes in attitudes and behaviors. Child Abuse Review, 19(4), 229-247. 